\title{
Atypical Gold Mineralization in an Orogenic Setting-The Bohaun Deposit, western Irish Caledonides
}

\author{
Paul A. Lusty ${ }_{\dagger}$, Jon Naden, John J. Bouch*, John A. McKervey
}

British Geological Survey, Kingsley Dunham Centre, Nicker Hill, Keyworth, Nottingham, UK

AND JAMES A. MCFARLANE

Omagh Minerals Limited, 56 Botera Upper Road, Omagh, County Tyrone, UK

Corresponding author: email, plusty@bgs.ac.uk

Present address: Pore Scale Solutions Limited, Riverside Cottage, Carwynnen, Camborne, Cornwall, TR14 9LR 


\begin{abstract}
The Bohaun gold deposit in County Galway, western Ireland is located in the Caledonian orogenic belt, proximal to a major accretionary boundary. The mineralization is hosted in a normal extensional fault, representing a zone of repeated extension and vein infilling of open cavities, within clastic sedimentary rocks, which have only reached the late diagenetic zone of low-grade metamorphism.

The mineralization consists of undeformed veins, stockworks and breccias. Quartz dominates all the veins and commonly displays multiple growth stages and a variety of classic epithermal textures, including comb, plumose and banded, indicative of low confining pressures. The veins have a simple mineralogy comprising quartz-sericite-chlorite with minor sulfides, hematite, rare visible gold, with a high silver content (up to $41 \mathrm{wt} \%$ ), and late barite and dolomite.

Vein quartz is associated with two fluids compositions: Type I with moderate to high salinity (8.0-23.6 wt \% NaCl equiv) and Type II with low to moderate salinity $(0.0-7.8 \mathrm{wt} \%$ $\mathrm{NaCl}$ equiv). $\mathrm{CO}_{2}$ contents in both fluid types are $<3.5 \mathrm{wt}$ percent. The majority of fluid inclusion homogenization temperatures range from 126 to $257^{\circ} \mathrm{C}$ and geologically constrained depth estimates $(\leq 5 \mathrm{~km})$ indicate maximum fluid inclusion trapping temperatures between 175 and $245^{\circ} \mathrm{C}$.

The geodynamic setting of Bohaun, which comprises a deformed continental margin of an allochthonous terrane, is typical of orogenic gold deposits. However, an orogenic association for the Bohaun mineralization is discounted on the basis of fluid inclusion evidence, atypical vein textures, gold grain composition and undeformed veins. While vein textures locally resemble those found in epithermal quartz-adularia mineralization, there is no obvious magmatic association and alteration is restricted to the veins and immediate host rocks.

The origin of the gold at Bohaun remains enigmatic. However, we favor an association with widespread Carboniferous or later mineralizing fluids and a model which involves transport and deposition of gold from a basinal brine type fluid, in a similar fashion to red-bed $\mathrm{Au}-\mathrm{Pd}$ mineralization. Bohaun provides further evidence that low temperature brines may be capable of generating economic grade gold mineralization, independent of other fluids.
\end{abstract}




\section{INTRODUCTION}

Orogenic gold deposits are typified by quartz-carbonate-dominant vein systems associated with deformed metamorphic terranes of all ages (Groves et al., 1998) and mineralization displays strong structural controls at a variety of scales. Deposits are most commonly located on second- or third-order structures in the vicinity of large-scale compressional or transpressional structures formed at convergent margins (Groves et al., 1998; Bierlein and Crowe, 2000; Groves et al., 2003). Goldfarb et al. (2005) identify gold deposits associated with the Caledonian Orogeny in the British Isles as an example of Palaeozoic orogenic gold mineralization. Indeed, Caledonian basement rocks north of the Iapetus suture in the British Isles contain numerous important orogenic gold prospects extending from the Mayo-Curlew Basin of western Ireland (Croagh Patrick and the mineralization of the Sheeffry Hills in County Mayo, including Cregganbaun: Thompson et al., 1992; Aherne et al., 1992; Wilkinson and Johnston, 1996) through the North Western Basement and Longford Down Massif (Curraghinalt, Cavanacaw and Clontibret: Steed and Morris, 1986; Morris et al., 1986; Cliff and Wolfenden, 1992; McCaffrey and Johnston, 1996; Earls et al., 1996; Parnell et al., 2000) and into Scotland (Cononish and Calliacher-Urlar Burn: Curtis et al., 1993; Ixer et al., 1997). The mineralization at Bohaun, which is the subject of this paper, is particularly distinctive and differs markedly from the occurrences listed above.

The Bohaun deposit is located to the south of Lough Kilbride, in northern Connemara, County Galway, Ireland (Fig. 1). North of Bohaun, gold mineralization occurs in two main geological settings. On the south side of Clew Bay auriferous quartz veins, including the Croagh Patrick mineralization, occur along the strike length of the Silurian quartzite belt. Further south gold mineralization occurs in the Ordovician rocks of the South Mayo Trough. The east-west-trending Cregganbaun Shear Zone extends through the Ordovician sequence with gold occurrences at many localities along its $33 \mathrm{~km}$ length (Thompson et al., 1992).

The Bohaun deposit was discovered in the late 1980s during a commercial regional geochemical sampling programme by Ovoca Gold Exploration plc. Elevated gold values were identified in association with a north-trending brecciated and silicified zone of Silurian rocks (Fig. 2). Limited exploration was conducted, including the drilling of three shallow inclined boreholes. Drilling intersected a silicified breccia zone containing limonite, chlorite, calcite, pyrite, chalcopyrite and visible gold, and extending to a vertical depth of at least $45 \mathrm{~m}$ (Ovoca Gold Exploration plc, unpub. data). Subsequent reconnaissance sampling identified a large and coherent zone of gold-bearing, silicified outcrops and boulders (Alba Mineral Resources plc, press release, 14 February 2006).

Here we present a range of field observations, petrographic information and fluid inclusion data to show that the deposit was formed at shallow depths and basinal brines played a significant role in the mineralization.

\section{REGIONAL GEOLOGICAL SETTING of BOHAUN}

Connemara is an allochtonous terrane within the western Irish Caledonides (Fig. 1: Draut and Clift, 2002), which were formed during the Caledonian Orogeny (McKerrow et al., 2000). This metamorphic terrane is situated within an arc-continent suture zone (Clew BayHighland Boundary line), resulting from closure of the Iapetus Ocean during the early Ordovician Grampian Orogeny (c. 475-462 Ma: Draut and Clift, 2002). The Connemara terrane is correlated with part of the Neoproterozoic Dalradian Supergroup in Scotland, a lithologically-varied sequence of folded and metamorphosed late Precambrian marine clastic sedimentary rocks and minor basic volcanic rocks (Harris et al., 1994). Adjacent to Connemara, the South Mayo Trough generally recognized as a forearc basin contains a thick 
succession of Ordovician volcanic and sedimentary rocks (Clift and Ryan, 1994; Friedrich et al., 1999a). The obscured contact between the Connermara terrane and the South Mayo Trough is inferred to be a strike-slip terrane boundary (Friedrich et al., 1999b). The Connemara Dalradian and rocks of the South Mayo Trough are unconformably overlain by Silurian (Llandovery <443 Ma) sedimentary rocks (Friedrich et al., 1999b: Fig. 1). To the south, Silurian strata extend inland east-south-east from south of Killary Harbour to the area around Lough Kilbride before disappearing under the Carboniferous rocks of Lough Mask. The Carboniferous of South Mayo and Connemara is subdivided into basal clastics and overlying carbonates (Graham et al., 1989). The Carboniferous (Dinantian) strata form the north-western margin of the economically significant 'Irish Midlands basin', named the 'North West Province' (Phillips and Sevastopulo, 1986; Johnston et al., 1996). Outside the Dalradian, metamorphic grade in this part of Irish Caledonides is generally very low, ranging from late diagenetic zone to upper anchizone (Rice and Williams, 2009).

The closest major igneous body to Bohaun is the Oughterard Granite (U-Pb age of 462.2 $\pm 0.5 \mathrm{Ma}$ ), $7 \mathrm{~km}$ to the south (Friedrich et al., 1999a). Late Caledonian granites are well developed in Connemara comprising the extensive Galway Granite and its satellite plutons, approximately $15 \mathrm{~km}$ south of Bohaun (Fig. 1). Feely et al. (2003) indicate that several phases of granite emplacement and plutonism extended over a period of c. $30 \mathrm{Ma}$ (c. 380-410 $\mathrm{Ma}$, based upon TIMS U-Pb ages for the granite and $\mathrm{Re}-\mathrm{Os}$ dates for associated molybdenite mineralization). Minor intrusions including felsites, quartz porphyries and lamprophyres associated with the intrusion of the Galway Granite occur in the Silurian strata extending inland east-south-east from south of Killary Harbour to the area around Lough Kilbride (Graham et al., 1989). The late Caledonian Corvock Granite (c. $387 \pm 12 \mathrm{Ma}$, based upon a $\mathrm{Rb}-\mathrm{Sr}$ date: O'Conner, 1989) intrudes the Silurian and Ordovician rocks of South Mayo and has been suggested as a possible heat source for the mobilization of mineralizing fluids associated with the 'shear-vein' deposits to the north of Bohaun (Fig. 1: Aherne et al., 1992).

The whole of Ireland is affected by late-Silurian to middle-Devonian Caledonian deformation (Phillips and Sevastopulo, 1986). In Connemara, this resulted in thrusting of Ordovician rocks over Silurian strata along the Salrock Thrust South of Killary harbour (Morris et al., 1995). East of the Maam Valley Fault the Silurian rocks are folded into a series of east-striking folds. East to east-south-east faulting developed in conjunction with the folding and was closely associated with prominent east-north-east faulting. In Connemara and South Mayo, the post-Dinantian structural trend is dominated by north-east-trending faults. Many of these structures represent reactivation of older basement structures. Some of the faults transecting the pre-Carboniferous basement show post-Dinantian reactivation. However, it is difficult to differentiate this from earlier fault movement (Graham et al., 1989).

\section{MATERIALS and METHODS}

\section{Field mapping and sampling}

Mapping of the Bohaun mineralization and host rocks was undertaken at a scale of 1:2500 (Fig. 2). Representative samples were collected from surface exposures throughout the strike length of the silicified breccia zone for mineralogical, mineral chemistry and fluid inclusion studies (Figs. 2, 3). The majority of auriferous samples and all the fluid inclusion samples analysed were obtained from a small $(10 \times 10 \mathrm{~m})$ well-exposed, intensely veined area (Fig. 2, 3 ). This area had been the focus of previous sampling campaigns, with the majority of visible gold samples being derived from this locality and with sporadic high gold values, up to 73 ppm in a one-meter channel sample (McFarlane, 2006). Furthermore, the exposure contained the full spectrum of quartz types present at Bohaun and provided excellent control on the vein 
relationships. This area was mapped in detail, at a scale of 1:25 (Fig. 3). A number of additional samples were collected from the limited outcrops along the strike length of the mineralized zone. However, these failed to yield material suitable for microthermometric analysis.

\section{Petrography}

Seventeen standard polished thin sections, representative of quartz veins and breccia (L26.1, L26.2, L26.4, L26.8, S0007, S0017, S0020, S0023A, L3), visible gold-bearing samples (VG05, VG06, VG12A, VG12B) and host rocks (L19, L39, L53, L69) were examined optically in transmitted and reflected light (samples located on Figs. 2, 3). Cathodoluminescence (CL) observations were made using an Oxford Instruments "miniCL" cathodoluminescence detector on samples VG06 and VG12B.

\section{Electron microprobe}

Microchemical mapping and quantitative point analyses were carried out on sample VG05 using a Cameca SX50 wavelength dispersive electron microprobe (EPMA). Selected areas were mapped for $\mathrm{Au}, \mathrm{Ag}, \mathrm{Cu}$ and $\mathrm{Hg}$ by WDS analysis at $15 \mathrm{kV}$ and $150 \mathrm{nA}$ with count times of 90 milliseconds. Subsequently, point analyses were performed for $\mathrm{Ag}, \mathrm{Cu}, \mathrm{S}, \mathrm{Pd}$ and $\mathrm{Fe}$ at operating conditions of $15 \mathrm{kV}$ and $20 \mathrm{nA}$ and then reanalysed at $30 \mathrm{kV}$ and $20 \mathrm{nA}$ so that $\mathrm{Hg}$ contents could also be determined.

\section{Fluid inclusion microthermometry}

Six fluid inclusion wafers (VG05, VG12A, comb2, S0008, S0010, S0011) were analysed microthermometrically, yielding over 200 determinations of salinity and homogenization temperature. Data were collected using a Linkam THM600 fluid inclusion heating-freezing stage, attached to a Leitz Ortholux II petrographic microscope, controlled by a TP91 programmer. Instrument calibration was done using synthetic fluid inclusion standards. Estimated analytical error is $\pm 0.2^{\circ} \mathrm{C}$ for low $\left(<50^{\circ} \mathrm{C}\right)$ and $\pm 2^{\circ} \mathrm{C}$ for higher $\left(>75^{\circ} \mathrm{C}\right)$ temperatures. The data are presented as last ice-melting temperatures, wt percent $\mathrm{NaCl}$ equivalent estimates, homogenization. Only equilibrium phase changes are reported. Salinity estimates and salt compositions were derived using the phase relations for experimentally determined salt-water-gas systems: $\mathrm{NaCl}-\mathrm{H}_{2} \mathrm{O}$ and $\mathrm{NaCl}-\mathrm{H}_{2} \mathrm{O}-\mathrm{KCl}$ (Sterner et al., 1988). Inclusions were classified as primary, pseudosecondary or secondary according to the criteria of Roedder (1984).

\section{RESULTS}

\section{Geology and structure}

The Bohaun deposit is located within a tract of Silurian rocks extending east of the Maam Valley Fault to the area around Lough Kilbride (Fig. 1). The Silurian succession at Bohaun ranges from Llandovery to Wenlock age, resting with marked unconformity on the Dalradian (Fig. 2). The oldest of the Silurian rocks, the Lough Mask Formation comprises a coarsegrained, commonly cross-bedded, purple sandstone. This is conformably overlain by blue to grey fossiliferous sandstones and mudrocks of the Kilbride Formation. Graded sandstones 
define the base of the Lettergesh Formation, the uppermost Silurian unit at Bohaun, which occurs only to the west of the mineralized fault zone.

The Silurian succession has been deformed into an east-striking, gently westerly plunging syncline, during regional deformation and subsequently faulted. The principal fault influencing the stratigraphy and controlling the mineralization is a steeply dipping, northtrending $\left(015^{\circ}\right)$, extensional normal fault which downthrows to the west, at between 56 and $77^{\circ}$. This fault offsets the late Silurian syncline developed at Bohaun. A number of additional brittle normal faults splay off the main structure. A north-north-east-trending fault causes the mineralized zone to bifurcate at its northern end. At the southern end of the mineralized zone two mineralized faults splay off the main structure. An additional high-angle mineralized fault occurs to the east of the main structure. Post-mineralization displacement is evident from an obvious fault plane displaying slickensides along the western margin of the silicified breccia body. This suggests that following silicification of the auriferous fault zone, displacement along the cemented fault zone gave way to displacement between the western side of the mineralized breccia body and the host rocks (Fig. 2). The structures and fault textures observed at Bohaun are evidence for brittle failure, within an extensional tectonic regime. Although the stratigraphy is folded and faulted, total strain appears relatively low, as evident from undeformed sedimentary features and textures (e.g. bedding structures and laminations, conglomerate clasts and fossils).

\section{Mineralization style and alteration}

The mineralization is represented by a north-trending brecciated and silicified fault zone, which is discontinuously exposed over a distance of approximately $1200 \mathrm{~m}$; a significant break in exposure of more than $200 \mathrm{~m}$ occurs towards the northern end (Figs. 2, 4A). Over its strike length the total width of the mineralized zone varies from 0.5 to $50 \mathrm{~m}$. The central part consists of a series of north-trending, anastomozing quartz-rich bodies measuring 1 to $2 \mathrm{~m}$ in width, punctuated by rafts of less silicified country rock (Fig. 3). These heavily silicified zones consist of a combination of discrete, undeformed veins, typically ranging in width from $1 \mathrm{~mm}$ to $20 \mathrm{~cm}$, pods of massive quartz and quartz cemented jigsaw breccias (Fig. 4B-C). This $15 \mathrm{~m}$ wide central zone grades laterally into a quartz stockwork, which diminishes in intensity with distance from the main structure. Veins within this zone pinch and swell and vary in width from millimeter size to about $10 \mathrm{~cm}$ (Fig. 4D-E). A considerably narrower zone of quartz veining with a similar orientation to the main body is located approximately $400 \mathrm{~m}$ east of the main mineralized fault zone (Fig. 2).

Quartz dominates all the veins and commonly displays multiple growth stages and a variety of textures, including saccharoidal, plumose and comb, disposed as crustiform bands and forming breccia cements, as indicated by field observations (Fig. 5A-H) and petrography (Table 1). Comb quartz and saccharoidal quartz are the most common textural variants (Fig. $5 \mathrm{~A}-\mathrm{D})$. Gold enrichment is preferentially associated with clay mineral- and hematite-rich areas of white to grey saccharoidal quartz (Fig. 5C-E). Crustiform textures (individual bands are millimetre size and within bands crystals have a consistent growth direction, perpendicular to the band: Fig. 5C-D), weakly developed colloform banding (Fig. 5E) and euhedral, locally, acicular crystals typical of open-space filling are common (Fig. 5F-G). Fresh sulfides are extremely rare in outcrop, although extensive limonitic staining and remnants of oxidized sulfide, probably pyrite, are common within the quartz (Fig. 5B, E, G). Rare occurrences of late-stage, well-developed, bladed crystals of dolomite and barite are found within vugs and cavities in the quartz at Bohaun (Fig. 5H). On an outcrop scale, visible gold shows a close association with wall-rock suggesting that fluid/wall rock interactions 
may have been important. The majority of gold-bearing hand specimens also contain altered wall rock fragments (Fig. 5B-D).

On a macro scale, alteration is dominated by intense silicification along and adjacent to the fault zone as evidenced by the extensive quartz veining, silicification of the immediate wall rocks and wall rock fragments within the veins (Figs. 4B-E, 5B-D). Veins do not display distinct alteration haloes. However, wall-rock fragments and host rock adjacent to the veins are altered to a distinct pastel green to grey color, contrasting with 'unmineralized' country rock and indicative of the development of clay minerals (Fig. 5B-D). These clay mineral-rich zones do not typically extend more than $30 \mathrm{~cm}$ from the vein margins. On a microscopic scale, wall-rocks to the veins and rock fragments entrained within the veins display clear alteration compared with 'unmineralized' country rock. Samples of unaltered metasedimentary rocks typically contain 50 to 80 percent quartz, with up to 20 percent clay minerals, including discrete laths of muscovite, up to $150 \mu \mathrm{m}$ size and interstitial to quartz grains of a similar size. In contrast, alteration of this lithology has resulted in replacement of the original rock with considerably finer-grained (typically $\sim 20 \mu \mathrm{m}$ size), intergrown quartz and clay mineral (up to $40 \%$ ) aggregates, dominated by sericite and chlorite.

\section{Vein and ore petrography}

Individual quartz veins show considerable variation in cathodoluminescence response (Fig. 6), reflecting the multiple quartz generations indicated by the banding in hand specimen (Fig. 5C-D). The relationships between individual quartz generations are complex. However, a clearly rhythmical depositional sequence is evident in which three quartz variants predominate: (i) comb or plumose quartz comprising acicular quartz crystals up to $4 \mathrm{~mm}$ in size; (ii) saccharoidal quartz $(10-200 \mu \mathrm{m})$; and (iii) an intergrowth of fine-grained (10-100 $\mu \mathrm{m})$ quartz (70\%) and sericite (30\%: Fig. 7A; Table 1). Gold is almost always associated with sericite-rich quartz and/or sericite- or chlorite-rich veinlets (Fig. 6A, B; 7A, C). These veinlets occur within the intergrown quartz-sericite material and saccharoidal quartz, orientated parallel to the vein margin (Fig. 6A). Gold grains hosted within the sericite or chlorite veinlets are relatively large, up to $1 \mathrm{~mm}$, and may enclose individual idiomorphic quartz crystals (Fig. 7B). Additional quartz-sericite-filled fractures are observed extending obliquely away from the main gold-bearing sericite veinlets (Fig. 6A). Discrete veinlets are not the only gold repository; gold grains typically up to $50 \mu \mathrm{m}$, occur within the intergrown quartz and sericite (Fig. 7D). Smaller gold grains $(5-10 \mu \mathrm{m})$ occur at grain boundaries and triple point junctions in association with clay minerals (Fig. 7E). Specular hematite and/or hematitic quartz is closely associated with the gold and areas of chlorite. The hematite either occurs at the edges of veinlets (Fig. Fig. 7B), in weakly defined iron-rich bands following the rhythmic layering, or forming halos around isolated gold grains (Fig. 7D). Fine-grained (up to $10 \mu \mathrm{m}$ ) chalcopyrite is locally associated with the specular hematite (Fig. 7F). 


\section{Gold grain geochemistry}

Gold grains in sample VG05 display both silvery-yellow and orange-yellow color variation in reflected light, indicating their variable Ag contents. Both types of gold occur adjacent to one another in grains of the same morphology. Follow-up EPMA on the gold grains indicates no systematic pattern to the Ag-variations. However, some grains show a zonation from a relatively Ag-rich rim to Ag-poor core (Figs. 8A, B, D-E). Point analyses indicate that the Ag contents vary from 16 to $21 \mathrm{wt}$ percent and 39 to $41 \mathrm{wt}$ percent defining a bimodal distribution (Fig. 8F; Table 2). Small and variable amounts of $\mathrm{Cu}$ (up to $0.14 \mathrm{wt} \%$ : Fig. $8 \mathrm{C}$ ) and $\mathrm{Hg}$ (up to $0.09 \mathrm{wt} \%$ ) are also present.

\section{Fluid inclusion microthermometry}

A fluid inclusion study was undertaken to characterize the nature of the fluids that introduced gold into the system and establish the relationships between fluid, quartz type and mineral paragenesis (Table 3). Microthermometric analysis was focused on primary and pseudosecondary fluid inclusions and particular attention was paid to sample VG05 (Fig. 9) as this demonstrates a clear paragenetic relationship between quartz-type and gold. Here, early gold-hosting quartz-sericite is overgrown by plumose quartz, which in turn is irregularly overgrown by saccharoidal quartz. Lastly coarse-grained euhedral quartz locally infills open space. Several quartz types are evident and gold is clearly spatially associated with intergrown quartz-sericite (Figs. 6, 7, 9). However, it is paragenetically later, as its distribution is restricted to quartz grain boundaries and small vugs lined with quartz microeuhedra (Fig. 7B, C, E). The intergrown quartz-sericite locally grades into plumose quartz (Fig. 9A, C, E) - neither this, nor later euhedral quartz, host gold. This strongly suggests, in sample VG05, that gold mineralization is bracketed by the deposition of these two types of quartz. Therefore, fluid inclusions hosted in this sample are the optimum for determining mineralizing fluid temperatures and compositions.

For all samples, at room temperature the fluid inclusion assemblage is dominated by L+V inclusions with liquid fills around 80 to 95 percent by volume (e.g. Fig. 10). Clathrate melting was not observed in any inclusion indicating that $\mathrm{CO}_{2}$ contents are $<3.5$ wt percent (Hedenquist and Henley, 1985). Low temperature microthermometric properties (Fig. 11; Table 3) indicate two distinct inclusion types: the first, Type I, is typified by low first-melting temperatures $\left(\mathrm{T}_{\mathrm{fm}}\right)$, mostly below $-30^{\circ} \mathrm{C}$, suggesting the presence of divalent cations, such as $\mathrm{Ca}^{2+}$, in addition to sodium. Moreover, in a significant number of Type I inclusions the presence of a salt hydrate (Table 3), which melts close to $-22^{\circ} \mathrm{C}$, confirms this. Final ice melting $\left(\mathrm{T}_{\mathrm{m} \text {-ice }}\right)$ is variable and is in the range -22.0 to $-5.1{ }^{\circ} \mathrm{C}(8-23.6 \mathrm{wt} \% \mathrm{NaCl}$ equiv) with a median value of $-8.8^{\circ} \mathrm{C}\left(12.6 \mathrm{wt} \% \mathrm{NaCl}\right.$ equiv). Homogenization temperatures $\left(\mathrm{T}_{\mathrm{h}}\right)$ range from 126 to $257^{\circ} \mathrm{C}$, with the exception of three inclusions with $\mathrm{T}_{\mathrm{h}}$ between 30 and $70^{\circ} \mathrm{C}$. The second, Type II, has high $\mathrm{T}_{\mathrm{fm}}$, generally much higher than $-20^{\circ} \mathrm{C}$, and is commonly characterized by rapid melting at temperatures within 1 to $3^{\circ} \mathrm{C}$ of $\mathrm{T}_{\mathrm{m} \text {-ice. }} \mathrm{T}_{\mathrm{m} \text {-ice }}$ varies between -5.0 and $-0.2^{\circ} \mathrm{C}\left(0\right.$ to $7.8 \mathrm{wt} \% \mathrm{NaCl}$ equiv), but is generally $>-2^{\circ} \mathrm{C}(3.3 \mathrm{wt} \% \mathrm{NaCl}$ equiv $)$. Homogenization temperatures range from 134 to $254^{\circ} \mathrm{C}$. A small number of secondary inclusions $(\mathrm{n}=5)$ in sample COMB2 exhibited high salinities $(11.0-21.1 \mathrm{wt} \% \mathrm{NaCl}$ equiv) and low $\mathrm{T}_{\mathrm{h}}\left(35-143^{\circ} \mathrm{C}\right)$.

The co-variation and frequency distribution of salinity and homogenization temperature are illustrated in Figure 11. This shows two distinct clusters of data: (i) approximately 40 percent of the data have salinities below $5 \mathrm{wt}$ percent $\mathrm{NaCl}$ equiv and (ii) about 35 percent of the data have salinities between 10 and 15 wt percent $\mathrm{NaCl}$ equiv. Most of the remainder 
$(15 \%)$ have intermediate salinities $(5-10 \mathrm{wt} \% \mathrm{NaCl}$ equiv) with rare high salinity $(>20 \mathrm{wt} \%$ $\mathrm{NaCl}$ equiv) variants. There is no obvious relationship between fluid inclusion type and quartz generation. This is illustrated petrographically in Figure 10A, where fluid inclusions exhibit salinity variation between 0.8 and 13 wt percent $\mathrm{NaCl}$ equiv (Table 3 ). Indeed, if all the analysed samples are taken into account, all quartz generations host both fluid inclusion types (Fig. 11; Table 3). However, within a single sample not all quartz types may be present and each quartz type within that sample may not host both inclusion types. For example, as discussed below, in VG05 saccharoidal quartz only hosts Type II inclusions. In terms of homogenization temperature, there is little obvious difference between the two inclusion types, though there is a suggestion that Type II inclusions may have slightly lower $\left(20-30^{\circ} \mathrm{C}\right)$ homogenization temperatures (Fig. 11).

Results of the detailed study of the gold-bearing sample VG05 are shown in Figure 12. The earliest quartz-sericite (Fig. 9A, C) mostly hosts Type II inclusions with salinities between 0.5 and 3.6 wt percent $\mathrm{NaCl}$ equiv $(\mathrm{n}=9)$ with one inclusion exhibiting Type I fluid inclusion characteristics with $\mathrm{T}_{\mathrm{fm}}$ at $-43^{\circ} \mathrm{C}$ and $\mathrm{T}_{\mathrm{m} \text {-ice }}$ at $-9.3^{\circ} \mathrm{C}(13.2 \mathrm{wt} \% \mathrm{NaCl}$ equiv). The plumose quartz that directly overgrows quartz-sericite (Fig. 9A, E) hosts both fluid inclusion types. Here, salinity for Type I inclusions ranges from 8.0 to $16.5 \mathrm{wt}$ percent $\mathrm{NaCl}$ equiv ( $\mathrm{n}=$ 37), while for Type II the range is 0.0 to 7.8 wt percent $\mathrm{NaCl}$ equiv ( $\mathrm{n}=16)$. Saccharoidal quartz (Fig. 9A, D) only hosts Type II inclusions and salinity ranges 0.3 to $3.3 \mathrm{wt}$ percent $\mathrm{NaCl}$ equiv $(\mathrm{n}=5)$. In the late euhedral quartz (Fig. 9A, D) the large majority of inclusions are Type I with salinities between 10.7 and $13.3 \mathrm{wt}$ percent $\mathrm{NaCl}$ equiv $(\mathrm{n}=17)$. Homogenization temperatures for fluid inclusions in each of the various quartz types are generally similar: (i) for quartz sericite they range from 151 to $215^{\circ} \mathrm{C}$, (ii) in plumose quartz they are between 145 and $218^{\circ} \mathrm{C}$, (iii) in saccharoidal quartz they range from 161 to $250^{\circ} \mathrm{C}$, and (iv) in late euhedral quartz they are between 126 and $176^{\circ} \mathrm{C}$.

\section{Fluid inclusion trapping temperatures}

Unless fluids are trapped on the liquid-vapour curve (boiling), fluid inclusion homogenization temperatures do not record mineralization temperatures and to estimate mineralization temperatures fluid inclusion homogenization temperature data need to be corrected for the effect of confining pressure. Here, we do not have an applicable geobarometer (e.g. iron contents in sphalerite-Lusk et al., 1993). However, on the basis of a gradient of $\sim 30$ to $35^{\circ} \mathrm{C} / \mathrm{km}$ predicted by lattice parameter b0 data (see Padan et al., 1982, for details) from mica (Rice and Williams, 2009; Kemp and Merriman, 2009), a mean illite crystallinity value of 0.48 for pelites from the Silurian metasedimentary rocks east of the Maam Fault (Rice and Williams, 2009), which hosts the Bohaun mineralization, constrains mineralization to the late diagenetic zone of low-grade metamorphism, with a maximum mineralization depth of $\sim 5 \mathrm{~km}$ according to the basin maturity chart of Merriman and Frey (1999). Textures and structures described above make lithostatic fluid pressure extremely unlikely. Thus estimated fluid pressures are probably no greater than $50 \mathrm{MPa}$. This indicates that pressure corrections are around $25-30^{\circ} \mathrm{C}$ at $50 \mathrm{MPa}$. 80 percent of the fluid inclusion homogenization data range between 150 and $220^{\circ} \mathrm{C}$, suggesting maximum trapping temperatures between and 175 and $250^{\circ} \mathrm{C}$ (Fig. 13), consistent with field observations.

\section{DISCUSSION}

The key geological characteristics of the Bohaun mineralization which have a bearing on its classification can be summarized as follows (Table 6): 
(i) It is located in the Caledonian orogenic belt, proximal to a major accretionary boundary (Clew Bay-Highland Boundary line) and a post-Caledonian carbonate basin (Fig. 1).

(ii) It is hosted in rocks which have only reached the late diagenetic zone of low-grade metamorphism.

(iii) The brittle nature of the ore-hosting structures sited within a normal extensional fault represents a zone of repeated extension and vein infilling of open cavities.

(iv) The mineralogy comprises quartz-sericite-chlorite with minor sulfides, hematite, rare visible gold (with a high silver content, up to $41 \mathrm{wt} \%$ ), and late barite and dolomite. The association of gold with the listed hydrothermal minerals, within a single quartz generation is evidence for a primary origin for the gold. In addition, the localized high silver content mitigates against a supergene origin.

(v) The undeformed veins display multiple growth stages and brecciation, classic epithermal-like textures and preservation of open-space. These indicate low strain and confining pressure.

(vi) There is no association with coeval volcanic rocks or obvious high-level magmatic activity.

(vii) Vein quartz is associated with two fluid compositions: Type I with moderate to high salinity (8.0-23.6 wt \% NaCl equiv) and Type II with low to moderate salinity $(0.0-7.8$ wt $\% \mathrm{NaCl}$ equiv). $\mathrm{CO}_{2}$ contents in both fluid types are $<3.5 \mathrm{wt}$ percent $(<0.85 \mathrm{~mol} \%)$;

(viii) Fluid inclusion homogenization temperatures range from 150 to $220^{\circ} \mathrm{C}$ and geologically constrained depth estimates $(\leq 5 \mathrm{~km})$ indicate maximum fluid inclusion trapping temperatures of 175 and $245^{\circ} \mathrm{C}$.

The geodynamic setting of Bohaun, which comprises a deformed continental margin of an allochthonous terrane, is typical of orogenic gold deposits (Groves, 2003: Table 6). However, an origin related to post-Caledonian mineralizing fluids is also possible. This is indicated by the proximity of: i) a significant late Palaeozoic (Dinantian) carbonate basin $(<10 \mathrm{~km}$ east: Graham et al., 1989) and; ii) fluid inclusion salinities more typical of basinal brines associated with Carboniferous and later mineralization in the British Isles (e.g. Ireland: Samson and Russell, 1987; Banks and Russell, 1992; Banks et al., 2002; O'Reilly et al., 1997; Wilkinson, 2010; Devon: Shepherd et al., 2005; Scotland: Samson and Banks, 1988; Curtis et al., 1993; Baron and Parnell, 2005). These two contrasting scenarios are discussed below.

\section{Orogenic gold}

Phanerozoic orogenic gold deposits are typically associated with low to medium greenschist facies turbiditic rocks (Bierlein and Crowe, 2000). Bohaun is hosted in rocks which have only reached the late diagenetic zone of low-grade metamorphism. Other gold deposits in western Ireland (e.g. Croagh Patrick and Cregganbaun-Fig. 1) resemble classical orogenic gold mineralization. At Croagh Patrick auriferous quartz veins are associated with shear zones in greeschist facies quartzites. Gold deposition was associated with unmixing of a $\mathrm{H}_{2} \mathrm{O}-\mathrm{CO}_{2}-\mathrm{NaCl}$ fluid at 240 to $320^{\circ} \mathrm{C}$ (Wilkinson and Johnston, 1996).

Although highly variable, veins in orogenic gold deposits typically consist of complex podiform quartz veins and replacement structures. Anhedral 'buck quartz' (milky to vitreous quartz, with tightly packed, interlocking crystals) is characteristic, with overprinting by ribbons, stylolites, spider veinlets and breccias. Veins are frequently lenticular in form, displaying banded margins and more massive interiors (Dowling and Morrison, 1990). Orogenic gold mineralization typically develops synkinematically, in association with at least one phase of penetrative deformation of the country rocks, resulting in a strong structural control (Groves et al., 2003). 
Paradoxically, the quartz veins at Bohaun do not resemble the orogenic mineralization described above. The undeformed veins, stockworks and breccias, displaying comb, plumose, banded quartz textures and euhedral acicular crystals, indicate precipitation in open-space (Dowling and Morrison, 1990), commonly regarded as typical of epithermal-style mineralization, rather than orogenic deposits. Vearncombe (1993) indicates that wall-parallel (e.g. crustiform) and radiating textures (e.g. plumose) in quartz veins are characteristic of open-space filling and gold deposits formed at high crustal levels. Furthermore, Simmons et al. (2005) indicate that banding is a common textural characteristic of epithermal quartzadularia deposits.

The fluid inclusion data provide an indication of the conditions of gold mineralization at Bohaun. These contrast strongly with orogenic gold deposits, which are typified by low salinity ( $\leq 6 \mathrm{wt} \% \mathrm{NaCl}$ equiv.), carbonic fluids ( 5 to $50 \mathrm{~mol}$ percent $\mathrm{CO}_{2}$ ) and temperatures in excess of $270^{\circ} \mathrm{C}$ (Bierlein and Crowe, 2000). The Bohaun data are more comparable with epithermal deposits (Simmons et al., 2005), in respect of maximum fluid temperatures of approximately $270^{\circ} \mathrm{C}$ and low $(<3.5 \mathrm{wt} \%) \mathrm{CO}_{2}$ content.

The oxidized nature of some of the sulfides could indicate that the gold is supergene in origin. However, hypogene gold when weathered typically develops thin $(20-40 \mu \mathrm{m})$ silver poor $(<1 \mathrm{wt} \%)$ rims (e.g. Hough et al., 2007). This contrasts with the relatively Ag-rich rim to Ag-poor core recorded from some grains at Bohaun (see Fig. 8 D, E). This mitigates against a supergene origin. Furthermore, the silver-rich (39-41 wt \%) gold is consistent with that found in epithermal environments (10-55\% Ag: Morrison et al., 1991) and contrasts with orogenic deposits (referred to in Morrison et al., 1991 as 'slate belt' type), which are typically associated with gold with $\leq 20$ percent Ag (Morrison et al., 1991). The silver content of bedrock gold from Croagh Patrick varies considerably between outcrops (medians are 5.3 and 14.9 wt \% Ag: Chapman et al., 2000). The relatively low-Ag variety (16-21 wt \%) of gold identified at Bohaun (Table 2) is comparable to the more Ag-rich gold from Croagh Patrick (Chapman et al., 2000). The Bohaun gold is less similar to bedrock samples from the Cregganbaun shear zone (medians for two localities are 8.5 and $10.1 \mathrm{wt} \% \mathrm{Ag}$ : Chapman et al., 2000). Alluvial gold from Croagh Patrick and the Cregganbaun shear zone indicates that a wider range of compositions is present. However, in both locations the vast majority of grains contain less than 20 percent $\mathrm{Ag}$ and there is no evidence of gold with 40 percent $\mathrm{Ag}$ as observed at Bohaun (Chapman et al., 2000).

Although Bohaun displays features that are similar in some respects to epithermal deposits (Table 6), these systems typically display a close temporal and spatial association with subaerial volcanism and intrusion of calc-alkalic magmas (Simmons et al., 2005), which appear to be absent at Bohaun.

At Bohaun the lack of deformation and quartz textures indicative of open space growth, at relatively shallow crustal levels are more characteristic of epithermal environments. Phanerozoic orogenic gold deposits in metasedimentary terranes rarely display epithermallike textures (e.g. Nesbitt et al., 1986; Dowling and Morrison, 1990; Herrington and Wilkinson; 1993; Bierlein and Crow, 2000; Craw et al., 2010). However, it may be significant that vuggy vein textures interpreted as indicative of open space growth are reported from the later quartz generations in the Caledonian age Curraghinalt gold deposit in Northern Ireland (Wilkinson et al., 1999). It is suggested that this is indicative of relatively shallow-level development of the mineralization ( $<10 \mathrm{~km}$ depth: Parnell et al., 2000).

\section{Late stage brines}

Ireland is an established metallogenic province, well known for the abundance of carbonate-hosted base metal deposits, rather than orogenic gold mineralization. Indeed, it is 
well documented that fluids similar to those encountered in Irish-type $\mathrm{Zn}-\mathrm{Pb}$ deposits have penetrated, leached metals from and mineralized the Lower Palaeozoic metasedimentary basement rocks (Russell, 1978; LeHuray et al., 1987; Dixon et al., 1990; Everett et al., 1999a; Everett et al., 1999b; Gleeson and Yardley, 2003; Wilkinson et al., 2005; Walshaw et al., 2006).

Irish-type carbonate-hosted base metal deposits are documented in a number of reviews and the reader is referred to these for details (e.g. Wilkinson, 2010 and references therein). In terms of the features observed at Bohaun the salient characteristics of the mineralization are discussed below.

In the Lower Palaeozoic metasedimentary basement, it expresses itself as veins within Silurian and Ordovician rocks, both below carbonate-hosted deposits and importantly in areas a considerable distance $(>30 \mathrm{~km})$ from known carbonate-hosted mineralization. In a study of vein systems developed in Lower Palaeozoic inliers (hosted in Silurian greywackes, mudstones and sandstones) of the Irish Midlands, Everett et al. (1999a) report convincing evidence for the regional circulation of fluids similar to those observed in carbonate-hosted Irish-type $\mathrm{Zn}-\mathrm{Pb}$ deposits within the Lower Palaeozoic basement. Vein orientations are closely controlled by local brittle faults and are thought to have developed during movement on these faults. Three veins types are identified, with varying mineralogy: (i) hematitic calcite-quartz \pm pyrite; (ii) quartz-calcite \pm sphalerite, galena, chalcopyrite, pyrite, barite; and (iii) ankerite-ferroan dolomite-quartz \pm sphalerite, pyrite. The latter two veins types are associated with weak to locally intense sericite-chlorite-carbonate alteration and sulfides are absent from some of these veins. Veins display subhedral to euhdral crystal development and at one locality veins are observed in association with quartz and ankerite cemented hydrothermal breccia. Ferroan dolomite and calcite, with minor pyrite and chalcopyrite frequently occur as late vug-fillings. Fluid inclusion data from two of the vein types display homogenization temperatures and salinities in the range of 123 to $238^{\circ} \mathrm{C}$ and 9.7 to $20.6 \mathrm{wt}$ percent $\mathrm{NaCl}$ equiv and support a genetic association with the economic carbonate-hosted base metal mineralization (Everett et al., 1999a). However, neither these veins nor the carbonate-hosted mineralization are known to be auriferous.

Elsewhere in the Caledonides of the British Isles, base metal mineralization occurs in Lower Palaeozoic and Dalradian rocks (Samson and Banks, 1988; Pattrick and Russell, 1989; Treagus et al., 1999). Notably at some of these localities gold and base metal mineralization are spatially associated e.g. the Wanlockhead-Leadhills mining district and Tyndrum in Scotland. In the Wanlockhead-Leadhills area, base metal mineralization occurs as galena, sphalerite and chalcopyrite in association with calcite, dolomite, ankerite, barite, quartz and pyrite, commonly forming the matrix of vein breccias. The mineralization also contains hematite and is thought to be associated with low temperature $\left(<150^{\circ} \mathrm{C}\right)$, high salinity $(19-30$ wt. \% $\mathrm{NaCl}$ equiv) modified meteoric water. A Lower Carboniferous (Dinantian) age is proposed for the mineralization (Samson and Banks, 1988). In the Tyndrum area, known for its gold mineralization (Earls et al., 1992; Curtis et al., 1993), base metal veins comprise quartz and contain galena, sphalerite and barite with minor chalcopyrite. The veins are thought to have developed from saline $\left(\sim 15 \mathrm{wt} . \% \mathrm{NaCl}\right.$ equiv.) fluids at 140 to $200^{\circ} \mathrm{C}$ (Curtis et al., 1993). It is proposed that the base metal mineralization is associated with an Early Carboniferous mineralising event (Treagus et al., 1999). The Carboniferous base metal mineralization described above is thought to be genetically related and coeval with the carbonate-hosted $\mathrm{Zn}-\mathrm{Pb}$ deposits of central Ireland (Patrick and Russell, 1989).

The following characteristics of the Bohaun deposit suggest that it may have a postCaledonian basinal brine affinity: (i) the proximity of a major Dinantian carbonate basin, representing a potential source of saline, basinal brines; (ii) the coincidence of abundant veining and jigsaw breccias with a brittle, normal fault suggests the veins developed during 
movement of the structures with which they are associated; (iii) fluid inclusion data with homogenization temperature ranging from 145 to $250^{\circ} \mathrm{C}$, and presence of the Type I fluid with moderate to high salinity (8.0-23.6 wt \% NaCl equiv.), compatible with that observed in base metal mineralization of the Irish Midlands; (iv) the mineralogy of the Bohaun veins, particularly the occurrence of hematite and chlorite with minor sulfides and barite and dolomite; (iv) the undeformed nature of the veins is evidence for a post-Caledonian age for the mineralization.

Wilkinson et al. (1999) present evidence for remobilization of gold by low-temperature, high-salinity fluids at Curraghinalt. The late brine, which deposited quartz, carbonate, barite and base metals sulflides had a modal homogenization temperature of $120^{\circ} \mathrm{C}$, salinity of $12-$ $21 \mathrm{wt} \% \mathrm{NaCl}$ equiv, and no identifiable $\mathrm{CO}_{2}$ and is of supposed basinal origin. It is not apparent whether the late brine introduced new gold or just remobilized pre-existing Caledonian mineralization, with the latter suggested as most likely (Parnell et al., 2000: Wilkinson et al. 1999). Parnell et al. (2000) indicate the later phase of mineralization at Curraghinalt is comparable to the base metal mineralization at Tyndrum in Scotland. A similar fluid to the late brine identified at Curraghinalt is associated with veins crosscutting the Croagh Patrick gold mineralization (Parnell et al., 2000) about $100 \mathrm{~km}$ to the south-west. This work suggests basinal brines of the type which caused remobilization of gold at Curraghinalt may have been widespread at the time with considerable movement along major structural discontinuities.

Evidence for mineralizing events associated with Carboniferous or later fluids in Connemara and South Mayo are limited. However, O'Reilly et al. (1997) propose that base metal-bearing veins, containing pyrite with carbonate, barite and minor chlorite/clay hosted within the Galway Granite, to the south of Bohaun are associated with a basinal brine from a Carboniferous basin. These veins are also comparable to Bohaun in terms of containing brecciated wall rock fragments, comb quartz and vugs. In addition, Jenkin et al. (1998) document a strong $210 \mathrm{Ma}$ regional fluid event that overprints Carboniferous dikes in the area. One of these altered dikes is within $20 \mathrm{~km}$ of Bohaun.

A similar scenario to that proposed for Curraghinalt could be envisaged at Bohaun. However, there is no evidence for precursor (most likely Caledonian) gold mineralization from which the gold could have been remobilized, as is clearly evident at Curraghinalt. Accordingly, we can only conclude that the fluids identified in the Bohaun mineralization (i.e. one low to moderate salinity and the other a moderate to high salinity fluid, at relatively low temperatures) were responsible for transporting and depositing the gold mineralization. Evidence for transport of gold by comparable fluids is seen in red-bed $\mathrm{Au}-\mathrm{Pd}$ mineralization e.g. Coronation Hill, Australia (Mernagh et al., 1994); South Devon, UK (Shepherd et al., 2005); and Bleida Far West, Morocco (Ghorfi et al., 2006). These deposits display remarkably similar features to Bohaun, typically including abundant hematite, sulphide-poor ore mineral assemblages, an association with brittle structures, open-space textures, variable to typically strongly saline fluids, at temperatures of $<300^{\circ} \mathrm{C}$. Chloritic alteration is also described from Bleida Far West (Ghorfi et al., 2006) and Coronation Hill (Mernagh et al., 1994). In common with Coronation Hill and South Devon, the Bohaun mineralization is located proximal to major unconformity. However, the corresponding platinum group metals and selenide mineral assemblages common in these deposits are absent at Bohaun.

\section{Genetic model}

Although hosted in the Caledonian orogenic belt, an orogenic association for the Bohaun mineralization is discounted on the basis of fluid inclusion evidence, atypical vein textures and gold composition and undeformed veins, providing permissive evidence for a post- 
Caledonian age. While the mineralization is reminiscent of epithermal mineralization there is no obvious magmatic association and alteration is restricted to the veins and the immediate host rocks. Accordingly we favor an association with widespread Carboniferous or later mineralizing fluids. A potential source of brines, containing sulfate consistent with the mineralogy observed at Bohaun (late carbonate and baryte), is dewatering of proximal Carboniferous basin sediments. Fluids of this type would have been available from the Carboniferous onwards and have been recognized elsewhere in western Ireland (O'Reilly et al., 1997; Jenkin et al., 1998). Evaporites are reported from Carboniferous basins both to the east and west of Connemara providing a possible source of sulphate (Anderton et al., 1979; Robeson et al., 1988).

The Silurian-Dalradian unconformity and the deep fracture zone separating the Connemara Dalradian from the Ordovician are likely to represent important regional fluid pathways. In the neighbouring $\mathrm{Zn}-\mathrm{Pb}$ province of the Irish Midlands there is clear evidence for regional flow of Lower Carboniferous ore forming fluids within the metasedimentary basement, to depths of $>3-5 \mathrm{~km}$ (Everett et al., 1999a). Furthermore, Caledonian structures in the British Isles are suggested to represent important fluid pathways for Carboniferous metalliferous fluids (Johnston et al., 1996; Baron and Parnell, 2005). In Connermara, metalliferous fluids potentially exploited both pre-existing Caledonian basement structures, reactivated in response to regional extension and contemporaneous Variscan structures.

The origin of the gold at Bohaun remains enigmatic: the absence of precursor Caledonian gold mineralization precludes remobilization on a deposit scale, suggesting a relatively lowtemperature brine has potentially mobilized gold over a significant distance. Links to lowtemperature basinal brines similar to those seen in red-bed Au-Pd mineralization or Irish-style base metal deposits seem stronger than an orogenic gold lineage.

\section{CONCLUSIONS}

The Bohaun gold deposit is located in the Caledonian orogenic belt, proximal to a postCaledonian carbonate basin. The mineralization is associated with a normal extensional fault system, interpreted to represent a zone of repeated extension and vein infilling of open cavities in folded, Silurian sedimentary rocks, displaying very low grade metamorphism. The mineralization takes the form of undeformed veins, stockworks and breccias and displays epithermal-like textures and preservation of open-space, indicative of low confining pressure. The mineralogy consists of quartz-sericite-chlorite with minor sulfides, hematite and gold, with a high silver content and late barite and dolomite. The mineralization displays no obvious association with magmatic activity. Two fluids compositions have been identified: Type I with moderate to high salinity (8.0-23.6 wt \% $\mathrm{NaCl}$ equiv) and Type II with low to moderate salinity $\left(0.0-7.8 \mathrm{wt} \% \mathrm{NaCl}\right.$ equiv). $\mathrm{CO}_{2}$ contents in both fluid types are $<3.5 \mathrm{wt}$ percent and fluid inclusion homogenization temperatures range from 150 to $220^{\circ} \mathrm{C}$ and geologically constrained depth estimates $(\leq 5 \mathrm{~km})$ indicate maximum fluid inclusion trapping temperatures between 175 and $245^{\circ} \mathrm{C}$.

Accordingly the Bohaun gold mineralization strongly contrasts with other gold deposits in western Ireland that are typically orogenic in style. Although mimicking epithermal mineralization in a number of respects, an association with relatively low-temperature, variable salinity fluids and a proximal Carboniferous basin favours an association with widespread Carboniferous or later mineralizing fluids.

The origin of the gold at Bohaun is enigmatic. However, we favour a model which involves transport and deposition of gold from a basinal brine type fluid, in a similar fashion to red-bed Au-Pd mineralization (e.g. Shepherd et al., 2005) rather than localized 
remobilization of orogenic gold mineralization as envisaged for Curraghinalt (e.g. Wilkinson et al., 1999). Bohaun provides further evidence that low temperature brines may be capable of generating economic grade gold mineralization, independent of other fluids.

\section{ACKNOWLEDGEMENTS}

We acknowledge the support of Alba Mineral Resources plc for logistical support during fieldwork at the Bohaun deposit and for providing historical data and assay results. Gus Gunn and Tim Colman are thanked for their valuable comments on the draft text and Simon Kemp for advice on illite crystallinity. This manuscript benefitted from reviews and comments by Dave Craw (U. Otago), Bob Foster (Bob Foster \& Associates Ltd) and Stuart Simmons (Economic Geology Associate Editor). PL, JN and JM publish with the permission of the Executive Director, British Geological Survey (NERC).

\section{REFERENCES}

Aherne, S., Reynolds. N.A., and Burke, D.J., 1992, Gold mineralisation in the Silurian and Ordovician of south Mayo, in Bowden, A.A., Earls. G., O’Connor PG., and Pyne JF., eds., The Irish Minerals Industry 1980-1990, Irish Association for Economic Geology, p. 39-49.

Anderton, R., Bridges, P.H., Leeder, M.R., and Sellwood, B.W., 1979, A dynamic stratigraphy of the British Isles, London: Allen and Unwin, $301 \mathrm{p}$.

Bakker, R.J., 2003, Package FLUIDS 1, Computer programs for analysis of fluid inclusion data and for modelling bulk fluid properties: Chemical Geology, v. 194, p. 3-23.

Banks, D.A., and Russell, M.J., 1992, Fluid mixing during ore deposition at the Tynagh base-metal deposit, Ireland: European Journal of Mineralogy, v. 4, p. 921-931.

Banks, D.A., Boyce, A.J., and Samson, I.M., 2002, Constraints on the Origins of Fluids Forming Irish Zn-Pb-Ba Deposits: Evidence from the Composition of Fluid Inclusions: Economic Geology, v. 97, p. 471-480.

Baron, M., and Parnell, J., 2005, Fluid evolution in base-metal sulphide mineral deposits in the metamorphic basement rocks of southwest Scotland and Northern Ireland: Geological Journal, v. 40, p. 3-21.

Bierlein, F.P., and Crowe, D.E., 2000, Phanerozoic Orogenic Lode Gold Deposits, in Hagemann, S.G., Brown P.E., eds., Gold in 2000: Reviews in Economic Geology 13, p. 103-139.

Bodnar, R.J., and Vityk M.O., 1994, Interpretation of microthermometric data for $\mathrm{H}_{2} \mathrm{O}-\mathrm{NaCl}$ fluid inclusions, in De Vivo, B., and Frezzotti, M.L., eds., Fluid Inclusions in Minerals, Methods and Applications Virginia Tech, Blacksburg, Virginia, p. 117-130.

Chapman, R.J., Leake, R.C., Moles, N.R., Earls. G., Copper, C., Harrington., K., and Berzins, R., 2000, The application of microchemical analysis of alluvial gold grain to the understanding of complex local and regional gold mineralization: a case study in the Irish and Scottish Caledonides: Economic Geology, v. 95, p. 1753-1773.

Cliff, D.C., and Wolfenden, M., 1992, The Lack gold deposit, Northern Ireland, in Bowden, A.A., Earls, G., O’Connor, P.G., and Pyne, J.F., eds., The Irish Minerals Industry 1980-1990, Irish Association for Economic Geology, p. 65-75.

Clift, P.D., and Ryan, P.D., 1994, Geochemical evolution of an Ordovician island arc, South Mayo, Ireland: Journal of the Geological Society, London, v. 151, p. 329-342. 
Craw, D., Upton, P., Yu, B., Horton, T., and Chen, Y., 2010, Young orogenic gold mineralisation inactive collisional mountains, Taiwan: Mineralium Deposita, v. 45, 631-646.

Curtis, S.F., Pattrick, R.A.D., Jenkin, J.R.T., Fallick, A.E., Boyce, A.J., and Treagus, J.E., 1993, Fluid inclusion and stable isotope study of fault-related mineralization in Tyndrum area, Scotland: Transaction of the Institute of Mining and Metallurgy section B Applied Earth Science, v. 102, p. 39-47.

Dixon, P.R., LeHuray, A.P., and Rye, D.M., 1990, Basement geology and tectonic evolution of Ireland as deduced from Pb isotopes: Journal of the Geological Society, London, v. 147, p. 121-132.

Dowling, K., and Morrison, G., 1990, Application of quartz textures to the classification of gold deposits using north Queensland examples, in Keays, R.R., Ramsay, W.R.H., and D.I., Groves., eds., The Geology of Gold Deposits: The Perspective in 1988, Economic Geology Monograph 6, p. 342-355.

Draut, A.E., and Clift, P.D., 2002, The origin and significance of the Delaney Dome Formation, Connemara, Ireland: Journal of the Geological Society, London, v. 159, p. 95-103.

Earls, G., Hutton, D.W., Wilkinson, J., Moles, N., Parnell, J., Fallick, A., and Boyce, A., 1996, The Gold Metallogeny of Northwest Northern Ireland: Volume One, Geological Survey of Northern Ireland Technical Report GSNI/96/6, 60p.

Earls, G., Parker, R.T.G., Clifford, J.A., and Meldrum, A.H., 1992, The geology of the Cononish gold-silver deposit, Grampian Highlands of Scotland, in Bowden, A.A., Earls G., O’Connor, P.G., and Pyne. J.F., eds., The Irish minerals industry 1980-1990: Dublin, Irish Association for Economic Geology, p. 89-103.

Everett, C.E., Wilkinson, J.J., and Rye, D.M., 1999a, Fracture-controlled fluid flow in the Lower Palaeozoic basement rocks of Ireland: implications for the genesis of Irish-type $\mathrm{Zn}-\mathrm{Pb}$ deposits, in McCaffrey, K.J.M., Lonergan, L,. and Wilkinson, J.J., eds., Fractures, Fluid Flow and Mineralization, Geological Society, London, Special Publications, v. 155, p. 247-276.

Everett, C.E., Wilkinson, J.J., Boyce, A.J., Ellam, R.M., Gleeson, S.A., Rye, D.M.,and Fallick, A.E., 1999b, The genesis of Irish-type $\mathrm{Zn}-\mathrm{Pb}$ deposits: Characterisation and origin of the principal ore fluid, in Stanley, C.J., et al., eds., Mineral deposits: Processes to processing: Rotterdam, Balkema, p. 845-848.

Feely, M., Coleman, D., Baxter, S., and Miller, B., 2003, U-Pb zircon geochronology of the Galway Granite, Connemara, Ireland: implications for the timing of late Caledonian tectonic and magmatic events and for correlations with Acadian plutonism in New England: Atlantic Geology, v. 39, p. 175-184.

Friedrich, A.M., Bowring, S.A., Martin, M.W., and Hodges, K.V, 1999a, Short-lived continental magmatic arc at Connemara, Ireland: implications for the age of the Grampian orogeny: Geology, v. 27, p. 27-30.

Friedrich, A.M., Hodges, K.V., Samuel, A., Bowring, S.A., and Martin, M.W., 1999b, Geochronological constraints on the magmatic, metamorphic and thermal evolution of the Connemara Caledonides, Western Ireland: Journal of the Geological Society, London, v. 156, p. 1217-1230.

Gleeson S.A., and Yardley, B.W.D., 2003, Surface-derived fluids in basement rocks: inferences from palaeohydrothermal-systems: Journal of Geochemical Exploration, v. 78-79, p. 61-65.

Goldfarb, R.J., Baker, T., Dubé, B., Groves, D.I., Hart, C.J.R., and Gosselin, P. (2005) Distribution, Character, and genesis of gold deposits in metamorphic terranes, in Hedenquist, J.W., Thompson, J.F.H., Goldfarb R.J., and Richards J.P., eds., Economic Geology and the Bulletin of the Society of Economic Geologists One Hundredth Anniversary Volume 1905-2005, Tulsa, Society of Economic Geologists, p. 407-450.

Ghorfi, M.E., Oberthür, T., Melcher, F., Lüders, V., El Boukhari, A., Maacha, L., Ziadi, R., and Baoutoul, H., 2006, Gold-palladium mineralization at Bleida Far West, Bou Azzer-El Graara Inlier, Anti-Atlas, Morocco: Mineralium Deposita, v. 41, p. 549-564.

Graham, J.R., Leake, B.E., and Ryan, P.D., 1989, The Geology of South Mayo, western Ireland. University of Glasgow, Scottish Academic Press, 75p. 
Groves, D.I., Goldfarb, R.J., Gebre-Mariam, M., and Hagemann, S.G., 1998, Orogenic gold deposits: A proposed classification in the context of their crustal distribution and relationship to other gold deposit types: Ore Geology Reviews, v. 13, p. 7-27.

Groves, D.I., Goldfarb, R.J., Robert, F., and Hart, C.J.R., 2003, Gold deposits in metamorphic belts: overview of current understanding, outstanding problems, future research, and exploration significance: Economic Geology, v. 98 , p. 1-29.

Harris, A.L., Haselock. P.J., Kennedy, M.J., Mendum, J.R., Long, C.B., Winchester, J.A., and Tanner, P.W.G., 1994, The Dalradian Supergroup in Scotland, Shetland and Ireland, in Gibbon, W., and Harris, A.L., eds., A revised correlation of Precambrian rocks of the British Isles, Geological Society, Special Report 22, p. 33-53.

Hedenquist, J.W., and Henley, R.E., 1985, The importance of $\mathrm{CO}_{2}$ on the freezing point measurements of fluid inclusions: Evidence from active geothermal systems and implications of epithermal ore deposition: Economic Geology, v. 80, p. 1379-1408.

Herrington, R.J., and Wilkinson, J.J., 1993, Collodial gold and silica in mesothermal vein systems: Geology, v. 21, p. 539-542.

Hitzman, M.W., and Beaty, D.W., 1996, The Irish Zn-Pb-(Ba) ore field, in Sangster, D.F., ed., Carbonate-hosted lead-zinc deposits, Society of Economic Geologists Special Publication 4, p. 112-143.

Hough R.M., Butt, C.R.M., Reddy, S.M., and Verrall, M., 2007, Gold nuggets: supergene or hypogene?: Australian Journal of Earth Sciences, v. 54, p. 959 - 964.

Ixer, R., Pattrick, R., Stanley, C., 1997, Geology, mineralogy and genesis of gold mineralization at CalliacharUrlar Burn, Scotland: Transaction of the Institute of Mining and Metallurgy section B Applied Earth Science, v. 106, p. 99-108.

Jenkin, G.R.T., Mohr, P., Mitchell, J.G., and Fallick, A.E., 1998, Carboniferous dykes as monitors of postCaledonian fluid events in West Connacht, Ireland: Transactions of The Royal Society of Edinburgh-Earth Sciences, v. 88, p. 225-243.

Johnston, J.D., Coller, D., Millar, G., and Critchley, M.F., 1996, Basement structural controls on Carboniferoushosted base metal mineral deposits in Ireland, in Strogen, P., Somerville, I.D., and Jones, L.L., eds., Recent advances in Lower Carboniferous Geology, Geological Society, London, Special Publication, 107, p.1-21.

Knight, C.L, and Bodnar, R.J., 1989, Synthetic fluid inclusions IX: Critical PVTX properties of $\mathrm{NaCl}_{-} \mathrm{H}_{2} \mathrm{O}$ solutions: Geochimica et Cosmochimica Acta, v. 53, p 3-8.

Kemp, S.J., and Merrimen, R. J., 2009, Polyphase lowgrade metamorphism of the Ingleton Group, northern England, UK: a case study of metamorphic inversion in a mudrock sequence: Geological Magazine, v. 146, p. 237-51.

LeHuray, A.P., Caulfield, J.B.D., Rye, D.M., and Dixon, P.R., 1987, Basement controls on sediment-hosted PbZn deposits: a lead isotope study of Carboniferous mineralization in Central Ireland: Economic Geology, v. 82, p. 1695-1709.

Long, C.B., and McConnell, B., 1995, Geology of Connemara Sheet 10, Geological Survey of Ireland.

Lusk, J., Scott, S.D., and Ford, C.E., 1993, Phase-relations in the Fe-Zn-S system to 5 kbars and temperatures between $325^{\circ} \mathrm{C}$ and $150^{\circ} \mathrm{C}$ : Economic Geology, v. 88, p. $1880-1903$.

McCaffrey, K.J.W., and Johnston, J.D., 1996, Fractal analysis of a mineralised vein deposit: Curraghinalt gold deposit, County Tyrone: Mineralium Deposita, v. 31, p. 52-58.

McFarlane, J., 2006, Characterisation of The Bohaun Mountain Gold System, County Galway, Ireland, unpublished MSc. thesis, University of Exeter, 104p. 
McKerrow, W.S., Niocaill, C.M., and Dewy, J.F., 2000, The Caledonian orogeny redefined: Journal of the Geological Society, London, v. 157, p. 1149-1154.

Mernagh, T.P., Heinrich, C.A., Leckie, J.F., Carville, D.P., Gilbert, D.J., Valenta, R.K., and Wyborn, L.A.I, 1994, Chemistry of low-temperature hydrothermal gold, platinum and palladium ( \pm uranium) mineralization at Coronation Hill, Northern Territory, Australia: Economic Geology, v. 89, p. 1053-785.

Merriman, R.J., and Frey, M., 1999, Patterns of very low-grade metamorphism in metapelitic rocks, in Frey, M. and Robinson, D., eds., Low-Grade Metamorphism, Blackwell Sciences Ltd., Oxford, p. 61-107.

Morris, J.H., Long, C.B., McConnell, B., and Archer, J.B., 1995, Geology of Connemara, Geological Survey of Ireland, p55.

Morris, J.H., Steed, G.M., and Wilbur, D.G., 1986, The Lisglassan-Tullybuck deposit, County Monaghan: SbAs-Au vein mineralization in Lower Palaeozoic greywackes, in Andrew, C.J., Crowe, R.W.A., Finlay, S., Pennell, W.M., and Pyne, J., eds., Geology and genesis of mineral deposits in Ireland: Dublin, Irish Association for Economic Geology, p. 103-120.

Morrison, G.W., Rose, W.J., and Jaireth, S., 1991, Geological and geochemical controls on the silver content (fineness) of gold in gold-silver deposits: Ore Geology Reviews, v. 6, p. 333-364.

Nesbitt, B.E., Murowchick, J.B., and Muehlenbachs, K., 1986, Dual origins of lode gold deposits in the Canadian Cordillera: Geology, v. 14, p.506-509.

Oakes, C.S., Bodnar, R.J., and Simonson, J.M., 1990, The system NaCl- $\mathrm{CaCl}_{2}-\mathrm{H}_{2} \mathrm{O}: 1$ the ice liquidus at 1 atm total pressure: Geochimica et Cosmochimica Acta, v. 54, p. 603-610.

O'Conner, P.J., 1989, Chemistry and Rb-Sr age of the Corvock Granite, Western Ireland: Geological Survey of Ireland Bulletin 4, p. 99-105.

O'Reilly C., Jenkin G.R.T., Feely, M., Alderton D.H.M., and Fallick, A.E., 1997, A fluid inclusion and stable isotope study of $200 \mathrm{Ma}$ of fluid evolution in the Galway Granite, Connemara, Ireland: Contributions to Mineralogy and Petrology, v. 129, p. 120-142.

Padan, A., Kisch, H.J., and Shagam, R., 1982, Use of the lattice parameter $b_{0}$ of dioctahedral illite/muscovite, for the characterisation of $\mathrm{P} / \mathrm{T}$ gradients of incipient metamorphism: Contributions to Mineralogy and Petrology v. 79, p. 85-95.

Parnell, J., Earls, G., Wilkinson, J., Hutton, D.W., Boyce, A.J., Fallick, A.E., Ellam, R.M., Gleeson, S.A., Moles, N.R., Carey, P.F., and Legg, I., 2000, Regional fluid flow and gold mineralization in the Dalradian of the Sperrin Mountains, Northern Ireland: Economic Geology, v. 95, p. 1389-1416.

Pattrick, R.A.D., and Russell, M.J., 1989, Sulphur isotopic investigation of Lower Carboniferous vein deposits of the British Isles: Mineralium Deposita, v. 24, p. 148-153.

Phillips, W.E.A, and Sevastopulo, G.D., 1986, The stratigraphic and structural setting of Irish mineral deposits, in Andrew, C.J., Crowe, R.W.A., Finlay, S., Pennell, W.M., and Pyne, J., eds., Geology and genesis of mineral deposits in Ireland: Dublin, Irish Association for Economic Geology, p. 1-30.

Rice, A.H.N., and Williams, D.M., 2009, Caledonian strike-slip terrane accretion in W. Ireland: insights from very low-grade metamorphism (illite-chlorite crystallinity and $b_{0}$ paramter): Geological Magazine, v. 147, p. 281-298.

Robeson, D., Burnett, R.D., and Clayton, N.G., 1988, The Upper Palaeozoic geology of the Porcupine, Erris and Donegal Basins, offshore Ireland: Irish Journal of Earth Sciences, v. 9, p.153-175.

Roedder, E., 1984, Fluid Inclusions: Mineralogical Society of America, Reviews in Mineralogy, v. 12, 644p. 
Russell, M.J., 1978, Downward-excavating hydrothermal cells and Irish type ore deposits: Importance of an underlying thick Caledonian prism: Institution of Mining and Metallurgy Transactions, Section B-Applied Earth Science, v. 87, p. B168-B171.

Samson, I.M., and Banks, D.A., 1988, Epithermal base-metal vein mineralization in the Southern Uplands of Scotland: Nature and origin of the fluids: Mineralium Deposita, v. 23, p. 1-8.

Samson, I.M., and Russell, M.J., 1987, Genesis of the Silvermines Zinc-Lead-Barite Deposit, Ireland: Fluid Inclusion and Stable Isotope Evidence: Economic Geology, v. 82, p. 371-394.

Shepherd, T.J., Bouch, J.E., Gunn, A.G., McKervey, J.A., Naden, J., Scrivener, R.C., Styles, M.T., Large, D.E., 2005, Permo-Triassic unconformity-related Au-Pd mineralization, South Devon, UK: new insights and the European Perspective: Mineralium Deposita, v. 40, p. 24-44.

Simmons, S.F., White, N.C., and John, D.A., 2005, Geological characteristics of epithermal precious and base metal deposits, in Hedenquist, JW, Thompson, J.F.H., Goldfarb, R.J., and Richards, J.P., eds., Economic Geology and the Bulletin of the Society of Economic Geologists One Hundredth Anniversary Volume 1905 2005, Tulsa, Society of Economic Geologists, p. 485-522.

Sterner, S.M., Hall, D.L., Bodnar, R.J., 1988, Synthetic fluid inclusions .4. Solubility relations in the system $\mathrm{NaCl}-\mathrm{KCl}-\mathrm{H}_{2} \mathrm{O}$ under vapor-saturated conditions: Geochimica et Cosmochimica Acta, v. 52, p. 989-1005.

Steed, G.M., and Morris, J.H., 1986, Gold mineralization in Ordovician greywackes at Clontibret, Ireland, in Keppie, J.D., Boyle, R.W., and Haynes, S.J., eds., Turbidite-hosted gold deposits: Geological of Association Canada, Special Paper, v. 32, p. 67-86.

Steele-MacInnes, M., Bodnar, R.J. and Naden, J., 2011, Numerical model to determine the composition of $\mathrm{H}_{2} \mathrm{O}-$ $\mathrm{NaCl}-\mathrm{CaCl}_{2}$ fluid inclusions based on microthermometric and microanalytical data: Geochimica et Cosmochimica Acta, v. 75, p.21-40.

Thompson, S.J., Shine, C.H., Copper, C., Halls, C., and Zhao, R., 1992, Shear-hosted gold mineralisation in Co. Mayo, Ireland, in Bowden, A.A., Earls. G., O'Connor PG., and Pyne JF., eds., The Irish Minerals Industry 1980-1990, Irish Association for Economic Geology, p. 39-49.

Treagus, J.E., Pattrick, R.A.D., and Curtis, S.F., 1999, Movement and mineralization in the Tyndrum Fault Zone, Scotland and its regional significance: Journal of the Geological Society, London, v. 156, p. 591-604.

Vanko, D.A., Bodnar, R.J., and Sterner, S.M., 1988, Synthetic fluid inclusions .8. Vapor-saturated halite solubility in part of the system $\mathrm{NaCl}-\mathrm{CaCl} 2-\mathrm{H}_{2} \mathrm{O}$, with application to fluid inclusions from oceanic hydrothermal systems: Geochimica et Cosmochimica Acta, v. 52, p. 2451-2456.

Vearncombe, J.R., 1993, Quartz vein morphology and implications for formation depth and classification of Archaean gold-vein deposits: Ore Geology Reviews, v. 8, p. 407-424.

Walshaw, R.D., Menuge, J.F., Tyrrell, S., 2006, Metal sources of the Navan carbonate-hosted base metal deposit, Ireland: $\mathrm{Nd}$ and $\mathrm{Sr}$ isotope evidence for deep hydrothermal circulation, Mineralium Deposita, v. 41, 803-819.

Wilkinson, J.J., and Johnston, J.D., 1996, Pressure fluctuations, phase separation, and gold precipitation during seismic fracture propagation: Geology, v. 24, p. 395-398.

Wilkinson, J.J., Boyce, A.J., Earls, G., and Fallick, A.E., 1999, Gold remobilization by low-temperature brines: evidence from the Curraghinalt gold deposit, Northern Ireland: Economic Geology v. 94, p.289-296.

Wilkinson, J.J., Everett, C.E., Boyce, A.J., Gleeson, S.A., and Rye, D.M., 2005, Intracratonic crustal seawater circulation and the genesis of subseafloor zinc-lead mineralization in the Irish orefield: Geology, v. 33, p. 805808.

Wilkinson, J.J., 2010, A Review of Fluid Inclusion Constraints on Mineralization in the Irish Ore Field and Implications for the Genesis of Sediment-Hosted Zn-Pb Deposits: Economic Geology, v. 105, p. 417-442. 
Fig. 1. Location of the Bohaun deposit and other gold occurrences in relation to the regional geology of South Mayo and Connemara (adapted from Aherne et al., 1992; Long and McConnell, 1995: Copyright Geological Survey of Ireland). CG Corvock Granite; OG Oughterard Granite; CP Croagh Patrick; CR Cregganbaun; MVF Maam Valley Fault; SRT Salrock Thrust.

Fig. 2. Geological map of the Bohaun gold occurrence showing the relationship between the mineralized zone and the host succession. Words in italic refer to geographical place names. The Irish National Grid is shown (Transverse Mercator projection).

Fig. 3. Map of detailed mapping and sampling area at Bohaun, showing the relationship between various quartz types and breccia zones. Note the color scheme relates to the dominant quartz type observed in the vein or exposure. The area is interpreted to represent a zone of repeated, dominantly east-west extension and vein infilling of open cavities. Figures 4,5 provide an illustration of the vein styles depicted on the map.

Fig. 4. Photographs showing the nature of the exposure at Bohaun and styles of quartz veining. A. View from detailed mapping area (Fig. 3) of the mineralized zone trending northwards along the ridge at Bohaun. B. Intense silicification, consisting of quartz veining and quartz cemented breccias close to the center of the fault zone. C. Discrete quartz veins up to $5 \mathrm{~cm}$ wide, on a general north-south-trend, forming a stockwork, and typical of the mineralization close to the center of the mineralized zone. D. Sub parallel quartz veins up to $20 \mathrm{~cm}$ wide, composed predominately of saccharoidal quartz, located approximately $10 \mathrm{~m}$ away from the centre of the mineralized zone. E. Less intense quartz stockwork on the periphery of the mineralized zone. Veins in the image are dominated by comb quartz, with open-space cavities visible.

${ }^{1}$ Abbreviations apply to Figures 4 to 7 : wall rock $=w r$, quartz $=Q$, comb quartz $=\mathrm{cbQ}$, plumose quartz $=\mathrm{plQ}$, euhedral quartz $=\mathrm{euQ}$, saccharoidal quartz $=\mathrm{sQ}$, intergrown quartzsericite $=\mathrm{scQ}, \mathrm{sc}=$ sericite, $\mathrm{ch}=$ chlorite, sericite veinlet $=\mathrm{scvn}$, chlorite veinlet $=$ chvn, gold $=\mathrm{Au}$, chalcopyrite $=\mathrm{cpy}$, hematite $=\mathrm{hm}$, barite $=\mathrm{ba}$, limonite $=\mathrm{lm}$

Fig. 5. Types of quartz mineralization observed at Bohaun. A. Comb quartz developed within a vein displaying open space. B. Brecciated, pastel green-grey altered wall rock fragments cemented by saccharoidal quartz. C. VG05, cross-section of an auriferous vein displaying rhythmic deposition of bands of prismatic crystals and saccharoidal quartz associated with hematitic staining and limonitic patches. An altered wall rock fragment extends along the lower edge of the image. D. VG06, weakly developed colloform banding displaying hematite rich bands. E. Saccharoidal quartz hosting visible gold in association with hematite. F. geode of comb quartz cementing breccia fragments. G. iron oxide stained asicular needles of quartz filling a geode. H. Late-stage bladed baryte developed within a quartz vein cementing altered wall rock fragments.

Fig. 6. SEM cathodoluminescence images showing variation in cathodoluminescence response of the quartz vein fill. The sections clearly demonstrate the rhythmic nature of the quartz deposition with bands of intergrown quartz and sericite, saccharoidal quartz, comb and plumose quartz. Hematite is associated with some of the quartz bands. Gold grains have been false colored yellow to highlight their locations. A. VG06, a band of intergrown quartz and sericite containing rare isolated gold grains is deposited on wall rock. Several episodes of quartz deposition have followed. Coarse gold grains occur within sericite veinlets orientated parallel to the vein margin. B. VG12B, a similar pattern of zonation is observed with 
alternating bands of intergrown quartz and sericite, saccharoidal quartz and plumose quartz displaying complex internal zoning. Towards the top right-hand corner of the image euhedral quartz has nucleated around a wall rock fragment. Gold is associated with relatively latestage chlorite veinlets orientated sub-parallel to the quartz banding.

Fig. 7. Photomicrographs showing textural relationships between quartz, gold, sericite, chlorite, hematite and chalcopyrite. A. VG06, rhythmic deposition of layers of intergrown quartz and sericite, saccharoidal quartz and comb quartz (xpl). Gold-bearing sericite veinlets run parallel to the quartz banding. B. VG06, a gold grain hosted by a sericite veinlet within saccharoidal quartz. Blebs of hematite occur within the quartz towards the top of the image (ppl). C. VG12B, an irregular shaped gold grain is associated with a chlorite veinlet hosted by intergrown quartz and sericite (ppl). D. VG06, An isolated gold grain closely associated with chlorite and surrounded by a hematite halo, hosted within intergrown quartz and sericite (ppl). E. VG12B, gold grains occupying quartz crystal boundaries (rl). F. VG12B, finegrained chalcopyrite associated with chlorite and weak hematite staining (rl).

Fig. 8. EPMA microchemical maps of gold grains from sample VG05. The color scales on the EPMA microchemical maps show relative variations in composition only, and do not necessarily represent variation from 0 to 100 percent. A-C. Variation in $\mathrm{Au}, \mathrm{Ag}$ and $\mathrm{Cu}$ content of gold grains. D. Variation in Ag content of adjacent grains of similar morphology. The elongated grain towards the centre of the image is Ag-rich whereas the grains towards the bottom and along the far left of the image are relatively Ag-poor. E. A gold grain illustrating zonation from a relatively Ag-rich rim to Ag-poor core. F. Scatter plot of Au (wt $\%$ ) against $\mathrm{Ag}(\mathrm{wt} \%)$, illustrating the bimodal distribution of values.

Fig. 9. Photomicrographs and image scans showing the paragenetic relationship between quartz type and gold. A. Section scan of a sample VG05, containing abundant sub millimetrescale gold. B. Unmineralized sample (COMB2). Insets $\mathrm{C}-\mathrm{G}$ are areas sampled for microthermometric analysis. C. Intergrown quartz-sericite and plumose quartz. D. Saccharoidal quartz (dark) and euhedral quartz (light). E. A gold-rich area comprising plumose (light area on margin of disk) and quartz-sericite (dark area in centre). F-G. Samples of comb quartz. Microthermometric properties of representative fluid inclusions from each generation of quartz were determined and are presented in Figures 10, 11 and Table 4. Gold is clearly spatially associated with quartz-sericite and fills small vugs lined with quartz micro-euhedra (white scale bar in insets $\mathrm{C}-\mathrm{G}$ is $0.5 \mathrm{~mm}$ long).

Fig. 10. Photomicrographs illustrating typical fluid inclusions (white scale bar in all photomicrographs is $50 \mu \mathrm{m})$. A. Fluid inclusions hosted in plumose quartz spatially associated with native gold (Fig. 9A; chip labelled C, sample VG05) - note that this area hosts both Type I and Type II fluid inclusions (Table 5). B. fluid inclusions hosted in euhedral quartz, (Fig. 11A; chip labelled D, sample VG05). C. Fluid inclusions hosted in plumose quartz (Fig. 9A; chip labelled E). D. Fluid inclusions hosted in comb quartz (Fig. 9B; chip labelled F, sample comb2). Illustrative microthermometric data for the numbered fluid inclusion are given in Table 5.

Fig. 11. Combined scattergram (A) and histogram plots (B, C), showing the distribution of bulk salinity and homogenization temperature according to quartz type. The range of salinities for Type I \& II inclusions is also indicated. 
Fig. 12. Scattergram illustrating fluid inclusion data for sample VG05 according to the paragenetic position of quartz-type (Fig. 9). Visible gold only occurs in the early quartzsericite.

Fig. 13. Pressure-temperature plot showing four isochores constructed for typical Type I and Type II fluid inclusions. The grey lines show pressure corrections assuming hydrostatic pressures of $50 \mathrm{MPa}$ for inclusions that homogenize at 150 (A) and $220^{\circ} \mathrm{C}(\mathrm{B})$. For both inclusion types and homogenization temperatures, these are around $25-30^{\circ} \mathrm{C}$ and indicate trapping temperatures between 175 and $250^{\circ} \mathrm{C}$ [isochores calculated using FLUIDS 1 Bakker (2003); with the equations of state of Bodnar and Vityk (1994) and Knight \& Bodnar (1989) — parameters used in the calculations are provided in Table 5]. 
Table 1. Illustrations and descriptions of the quartz textures recorded at Bohaun

\begin{tabular}{lll}
\hline Texture type & Grain size/form \\
\hline Comb quartz (cbQ) & Typically prismatic crystals, parallel-orientated \\
Plumose quartz (plQ) & $\begin{array}{l}\text { Typically coarse/prismatic crystals, parallel- } \\
\text { orientated with internal zoning and feather like } \\
\text { structures }\end{array}$ \\
Saccharoidal quartz (sQ) & $\begin{array}{l}\text { Randomly distributed, fine-grained subhedral } \\
\text { anhedral crystals with little or no clay minerals }\end{array}$ \\
Euhedral quartz (euQ) & $\begin{array}{l}\text { Randomly distributed subhedral-anhedral crystals } \\
\text { intergrown with abundant sericite }\end{array}$
\end{tabular}

Table 2. Microprobe data for gold. $\mathrm{Au}, \mathrm{Ag}, \mathrm{Cu}, \mathrm{Pd}, \mathrm{Fe}$ and $\mathrm{S}$ analyses presented are at $15 \mathrm{kV}$ and $\mathrm{Hg}$ at $30 \mathrm{kV}$. Note the relatively Ag-rich nature of some of the gold grains from Bohaun

\begin{tabular}{lcccccccr}
\hline \hline $\begin{array}{l}\text { Analysis } \\
\text { point }\end{array}$ & $\begin{array}{c}\mathrm{Au} \\
\text { wt \% }\end{array}$ & $\begin{array}{c}\mathrm{Ag} \\
\text { wt \% }\end{array}$ & $\begin{array}{c}\mathrm{Cu} \\
\text { wt \% }\end{array}$ & $\begin{array}{c}\mathrm{Pd} \\
\text { wt \% }\end{array}$ & $\begin{array}{c}\mathrm{Fe} \\
\text { wt \% }\end{array}$ & $\begin{array}{c}\mathrm{S} \\
\text { wt \% }\end{array}$ & $\begin{array}{c}\mathrm{Hg} \\
\text { wt \% }\end{array}$ & $\begin{array}{r}\text { Total } \\
\text { wt \% }\end{array}$ \\
\hline 1 & 59.68 & 39.55 & 0.00 & 0.00 & 0.02 & 0.01 & 0.00 & 99.26 \\
2 & 81.92 & 17.34 & 0.00 & 0.00 & 0.00 & 0.00 & 0.00 & 99.27 \\
3 & 79.15 & 21.00 & 0.14 & 0.00 & 0.06 & 0.00 & 0.00 & 100.34 \\
4 & 82.64 & 17.32 & 0.00 & 0.00 & 0.00 & 0.01 & 0.00 & 99.97 \\
5 & 58.21 & 40.69 & 0.05 & 0.00 & 0.02 & 0.05 & 0.00 & 99.02 \\
6 & 60.25 & 39.07 & 0.00 & 0.00 & 0.02 & 0.02 & 0.09 & 99.35 \\
7 & 60.54 & 38.98 & 0.09 & 0.00 & 0.05 & 0.05 & 0.00 & 99.71 \\
8 & 84.37 & 16.37 & 0.12 & 0.00 & 0.00 & 0.00 & 0.00 & 100.87 \\
9 & 83.83 & 16.22 & 0.00 & 0.00 & 0.00 & 0.02 & 0.00 & 100.07 \\
10 & 83.84 & 16.57 & 0.13 & 0.00 & 0.04 & 0.02 & 0.00 & 100.59 \\
11 & 81.02 & 18.74 & 0.06 & 0.00 & 0.02 & 0.01 & 0.00 & 99.84 \\
12 & 80.46 & 19.97 & 0.00 & 0.00 & 0.04 & 0.00 & 0.00 & 100.47 \\
13 & 82.76 & 16.79 & 0.08 & 0.00 & 0.00 & 0.01 & 0.00 & 99.64 \\
14 & 59.68 & 39.55 & 0.00 & 0.00 & 0.02 & 0.01 & 0.00 & 99.26 \\
\hline \hline
\end{tabular}

Table 3. Summary fluid inclusion data for the Bohaun gold mineralization differentiated by fluid inclusion and quartz type. Type I inclusions tend to occur preferentially in euhedral and plumose quartz 


\begin{tabular}{|c|c|c|c|c|c|c|c|c|c|}
\hline \multirow{3}{*}{ Measurement } & \multirow{3}{*}{ Quartz type } & \multicolumn{8}{|c|}{ Fluid inclusion type } \\
\hline & & \multicolumn{4}{|c|}{ Type I } & \multicolumn{4}{|c|}{ Type II } \\
\hline & & n. & Min. & Max. & Med. & $\mathrm{n}$. & Min. & Max. & Med. \\
\hline \multirow{6}{*}{ 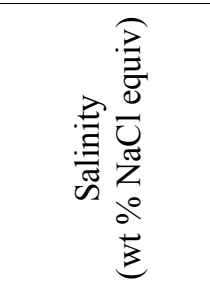 } & all quartz types & 131 & 8 & 23.6 & 12.6 & 76 & 0.0 & 7.8 & 0.8 \\
\hline & comb & 21 & 8.8 & 23.6 & 11.3 & 24 & 0.7 & 7.8 & 1.2 \\
\hline & euhedral & 47 & 9.2 & 15.5 & 12.4 & 17 & 0.0 & 6.4 & 0.8 \\
\hline & $\begin{array}{l}\text { intergrown quartz- } \\
\text { sericite }\end{array}$ & 10 & 10 & 20.3 & 13.2 & 14 & 0.5 & 4.9 & 0.8 \\
\hline & plumose & 42 & 8 & 16.5 & 12.8 & 16 & 0.0 & 7.8 & 2.15 \\
\hline & saccharoidal & 11 & 12.6 & 13.6 & 13.1 & 5 & 0.3 & 3.3 & 0.8 \\
\hline \multirow{6}{*}{ 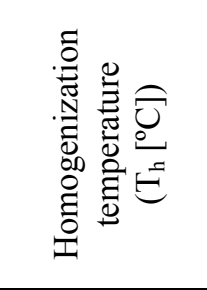 } & all quartz types & 129 & 35 & 257 & 163 & 73 & 134 & 254 & 187 \\
\hline & comb & 21 & 35 & 194 & 178 & 22 & 150 & 219 & 195 \\
\hline & euhedral & 47 & 116 & 257 & 154 & 17 & 134 & 254 & 192 \\
\hline & $\begin{array}{l}\text { intergrown quartz- } \\
\text { sericite }\end{array}$ & 10 & 141 & 172 & 156 & 14 & 151 & 215 & 180 \\
\hline & plumose & 42 & 140 & 245 & 171 & 15 & 149 & 206 & 185 \\
\hline & saccharoidal & 9 & 154 & 178 & 158 & 5 & 161 & 250 & 240 \\
\hline \multirow{6}{*}{ 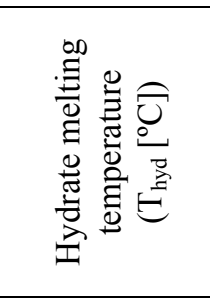 } & all quartz types & 32 & -23.5 & -22 & -22 & \multirow{6}{*}{\multicolumn{4}{|c|}{$\begin{array}{l}\text { No hydrate melting was } \\
\text { observed in any Type II } \\
\text { fluid inclusions }\end{array}$}} \\
\hline & comb & 3 & -22 & -22 & -22 & & & & \\
\hline & euhedral & 14 & -22.9 & -22 & -22 & & & & \\
\hline & $\begin{array}{l}\text { intergrown quartz- } \\
\text { sericite }\end{array}$ & 3 & -23.5 & -22 & -23 & & & & \\
\hline & plumose & 12 & -23.3 & -22 & -22 & & & & \\
\hline & saccharoidal & \multicolumn{4}{|c|}{ Hydrate melting not observed } & & & & \\
\hline \multirow{6}{*}{ 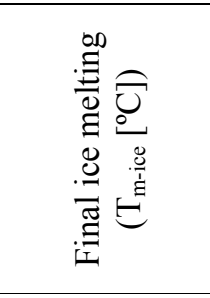 } & all quartz types & 131 & -22 & -5.1 & -8.8 & 73 & -5 & -0.2 & -0.5 \\
\hline & comb & 21 & -22 & -5.7 & -7.7 & 24 & -5 & -0.4 & -0.7 \\
\hline & euhedral & 47 & -11.5 & -6 & -8.6 & 15 & -4 & -0.5 & -0.5 \\
\hline & $\begin{array}{l}\text { intergrown quartz- } \\
\text { sericite }\end{array}$ & 10 & -17.6 & -6.5 & -9.3 & 14 & -3 & -0.3 & -0.5 \\
\hline & plumose & 42 & -12.7 & -5.1 & -8.95 & 15 & -5 & -0.4 & -1.6 \\
\hline & saccharoidal & 11 & -9.7 & -8.8 & -9.2 & 5 & -2 & -0.2 & -0.5 \\
\hline \multirow{6}{*}{  } & all quartz types & 120 & -51 & -10 & -30 & 61 & -39 & -1 & -3 \\
\hline & comb & 20 & -51 & -20 & -24 & 24 & -25 & -2 & -4 \\
\hline & euhedral & 47 & -45 & -12 & -30 & 17 & -35 & -1 & -2 \\
\hline & $\begin{array}{l}\text { intergrown quartz- } \\
\text { sericite }\end{array}$ & 6 & -50 & -30 & -41.5 & 5 & -4 & -2 & -2 \\
\hline & plumose & 38 & -49 & -10 & -37 & 15 & -39 & -1 & -4 \\
\hline & saccharoidal & \multicolumn{4}{|c|}{ First melting not observed } & \multicolumn{4}{|c|}{ First melting not observed } \\
\hline
\end{tabular}

Table 4. Illustrative microthermometric data for a range of fluid inclusions hosted in different quartz types. Data are for the quartz types and fluid inclusion inclusions shown in Figs. 9, 10.

\begin{tabular}{lllllllllll}
\hline \hline Sample & Chip $^{2}$ & FI & $\mathrm{T}_{\mathrm{fm}}$ & $\mathrm{T}_{\text {m-ice }}$ & $\mathrm{T}_{\text {hyd }}$ & $\mathrm{T}_{\mathrm{h}}$ & FI & Size & $\mathrm{NaCl}$ & Quartz
\end{tabular}




\begin{tabular}{|c|c|c|c|c|c|c|c|c|c|c|}
\hline \multirow[t]{2}{*}{ Number } & & \multirow[t]{2}{*}{ No. $^{3}$} & & & \multicolumn{5}{|c|}{ type ${ }^{4}$} & \multirow[t]{2}{*}{ type } \\
\hline & & & ${ }^{\circ} \mathrm{C}$ & ${ }^{\circ} \mathrm{C}$ & ${ }^{\circ} \mathrm{C}$ & ${ }^{\circ} \mathrm{C}$ & & $\mu \mathrm{m}$ & $\begin{array}{l}\text { wt } \% \\
\text { equiv }\end{array}$ & \\
\hline VG05 & $\mathrm{C}$ & A 1 & -43 & -8.0 & -23.0 & 159 & $\mathrm{P}$ & 19 & -11.8 & plumose \\
\hline VG05 & $\mathrm{C}$ & A 2 & & & & 185 & $\mathrm{P}$ & 28 & & plumose \\
\hline VG05 & $\mathrm{C}$ & A 3 & -10 & -6.7 & & 171 & $\mathrm{P}$ & 15 & 10.1 & plumose \\
\hline VG05 & $\mathrm{C}$ & A 4 & -4 & -2.2 & & 153 & $\mathrm{P}$ & 7 & 3.6 & plumose \\
\hline VG05 & $\mathrm{C}$ & A 5 & -4 & -0.5 & & 159 & $\mathrm{P}$ & 6 & 0.8 & plumose \\
\hline VG05 & $\mathrm{C}$ & A 6 & -4 & -1.0 & & 185 & $\mathrm{P}$ & 9 & 1.7 & plumose \\
\hline VG05 & D & B 1 & -30 & -8.5 & -22.8 & 138 & PS & 35 & 12.4 & euhedral \\
\hline VG05 & $\mathrm{D}$ & B 2 & -30 & -8.5 & -22.0 & 135 & PS & 20 & 12.4 & euhedral \\
\hline VG05 & D & B 3 & -30 & -8.5 & -22.0 & 146 & PS & 12 & 12.4 & euhedral \\
\hline VG05 & $\mathrm{D}$ & C 1 & -48 & -10.5 & & 177 & $\mathrm{P}$ & 18 & 14.5 & plumose \\
\hline VG05 & D & C 2 & -29 & -10.2 & & 191 & $\mathrm{P}$ & 5 & 14.2 & plumose \\
\hline VG05 & $\mathrm{D}$ & C 3 & -29 & -10.2 & & 218 & $P$ & 6 & 14.2 & plumose \\
\hline COMB2 & $\mathrm{E}$ & D 1 & -23 & -8.2 & & 180 & $\mathrm{P}$ & 14 & 11.9 & comb \\
\hline COMB2 & E & D 2 & -23 & -7.6 & & 163 & $P$ & 19 & 11.2 & comb \\
\hline COMB2 & $\mathrm{E}$ & D 3 & -23 & -8.2 & & 188 & $\mathrm{P}$ & 10 & 11.9 & comb \\
\hline
\end{tabular}

${ }^{1}$ Abbreviations: fluid inclusion $=\mathrm{FI}$, temperature at which first liquid was observed $=\mathrm{T}_{\mathrm{fm}}$, final ice melting temperature $=\mathrm{T}_{\mathrm{m} \text {-ice }}$, final hydrate melting temperature $=\mathrm{T}_{\text {hyd }}$

${ }^{2}$ Letters refer to labels in Fig. 9

${ }^{3}$ Letters and numbers refer to numbered fluid inclusion depicted in Fig. 10 (e.g. A1 is fluid inclusion \# 1 in Fig. 10A)

${ }^{4} \mathrm{P}=$ primary, $\mathrm{PS}=$ pseudosecondary

Table 5. Data used in calculating isochores presented in Fig. 13. Isochore calculated using FLUIDS 1 Bakker (2003); with the equations of state of Bodnar and Vityk (1994) and Knight \& Bodnar (1989).

\begin{tabular}{ccccccc}
\hline \hline $\begin{array}{c}{ }^{1} \mathrm{~T}_{\mathrm{h}} \\
{ }^{\circ} \mathrm{C}\end{array}$ & $\begin{array}{c}\mathrm{P}_{\mathrm{h}} \\
\mathrm{MPa}\end{array}$ & $\begin{array}{c}\mathrm{P}_{300} \\
\mathrm{MPa}\end{array}$ & $\begin{array}{c}{ }^{1} \text { Salinity } \\
\text { wt } \% \text { NaCl } \\
\text { equiv }\end{array}$ & $\begin{array}{c}\text { Density } \\
\mathrm{g} / \mathrm{cc}\end{array}$ & $\begin{array}{c}\text { Molar volume } \\
\text { cc/mol }\end{array}$ & $\begin{array}{c}\text { Inclusion } \\
\text { type }\end{array}$ \\
\hline 150 & 0.35 & 263 & 13.0 & 1.00113 & 19.7734 & Type I \\
220 & 1.31 & 132 & 13.0 & 0.94762 & 20.8810 & Type I \\
150 & 0.35 & 317 & 0.5 & 0.92499 & 19.5438 & Type II \\
220 & 1.31 & 118 & 0.5 & 0.84241 & 21.4597 & Type II \\
\hline \hline
\end{tabular}

${ }^{1}$ Salinity and $\mathrm{T}_{\mathrm{h}}$ data are from modal compositions of Type I and Type II fluid inclusions. 
Table 6. Comparison of the characteristics of the Bohaun mineralization with orogenic gold mineralization, quartz-adularia epithermal mineralization and basement-hosted veins in the Irish Midlands.

\begin{tabular}{|c|c|c|c|c|c|c|}
\hline Characteristic & Orogenic gold deposits & Bohaun & $\begin{array}{l}\text { Quartz-adularia epithermal } \\
\text { deposits }\end{array}$ & Bohaun & $\begin{array}{l}\text { Basement-hosted veins in the } \\
\text { Irish Midlands }\end{array}$ & Bohaun \\
\hline Tectonic setting & $\begin{array}{l}\text { Deformed continental margins } \\
\text { mainly of allochthonous } \\
\text { terranes }{ }^{1}\end{array}$ & $\checkmark$ & $\begin{array}{l}\text { Volcanic arcs at convergent } \\
\text { plate margins, intra-arc, back- } \\
\text { arc, and postcollisional rift } \\
\text { settings }\end{array}$ & $x$ & $\begin{array}{l}\text { Complex fault-controlled } \\
\text { basins and high standing- } \\
\text { platforms, indicating an } \\
\text { extensional tectonic regime }\end{array}$ & $\checkmark^{4}$ \\
\hline $\begin{array}{l}\text { Structural } \\
\text { setting }\end{array}$ & $\begin{array}{l}\text { Adjacent to 'first order', } \\
\text { transcrustal structures } 5 \text { ' }\end{array}$ & $\checkmark$ & $\begin{array}{l}\text { Extension-transtension } \\
\text { second- and third-order } \\
\text { structures, dilational jogs, } \\
\text { brittle fracturing }^{2}\end{array}$ & $\checkmark$ & $\begin{array}{l}\text { Closely related to high angle, } \\
\text { brittle normal fault zones }\end{array}$ & $\checkmark$ \\
\hline $\begin{array}{l}\text { Genetically } \\
\text { related rocks }\end{array}$ & $\begin{array}{l}\text { Immediate host rocks are not a } \\
\text { dominant factor in controlling } \\
\text { the mineralization }{ }^{5}\end{array}$ & na & $\begin{array}{l}\text { Volcanics: andesite- } \\
\text { rhyodacite, bimodal rhyolite- } \\
\text { basalt, alkalic }{ }^{2}\end{array}$ & $x$ & $\begin{array}{l}\text { Lower Palaeozoic } \\
\text { metasedimentary rocks, } \\
\text { beneath or adjacent to } \\
\text { carbonates }\end{array}$ & $\checkmark$ \\
\hline Host rocks & $\begin{array}{l}\text { Widely variable, commonly } \\
\text { thick sequences of marine } \\
\text { sedimentary rocks } 5\end{array}$ & $\checkmark$ & $\begin{array}{l}\text { Domes, diatremes, } \\
\text { pyroclastics and sedimentary } \\
\text { rocks }{ }^{2}\end{array}$ & $x$ & $\begin{array}{l}\text { Lower Palaeozoic } \\
\text { metasedimentary rocks }\end{array}$ & $\checkmark$ \\
\hline $\begin{array}{l}\text { Metamorphism } \\
\text { of host rocks }\end{array}$ & $\approx$ greenschist facies $^{5}$ & $x$ & Essentially unmetamorphosed & $\checkmark$ & Lowest greenschist facies ${ }^{6}$ & $x$ \\
\hline Deposit form & $\begin{array}{l}\text { Variable, large veins, complex } \\
\text { vein array, saddle reef }\end{array}$ & $x$ & $\begin{array}{l}\text { Vein, vein swarms, } \\
\text { hydrothermal breccia, } \\
\text { stockworks, disseminations }^{2}\end{array}$ & $\checkmark$ & Veins, breccias ${ }^{6}$ & $\checkmark$ \\
\hline Gangue & $\begin{array}{l}\text { Quartz, minor Fe-Mg } \pm \mathrm{Ca} \\
\text { carbonates, alkali feldspar, } \\
\text { sericite, chlorite }^{5}\end{array}$ & $\checkmark^{7}$ & $\begin{array}{l}\text { Quartz and/or chalcedony } \pm \\
\text { adularia, carbonate, barite, } \\
\text { rhodochrosite, K mica (illite } \\
\text { or sericite), chlorite, hematite }\end{array}$ & $\checkmark^{8}$ & $\begin{array}{l}\text { Quartz, hematitic calcite, } \\
\text { dolomite, barite }^{6}\end{array}$ & $\checkmark$ \\
\hline
\end{tabular}


Sulfides

Commonly pyrite and

arsenopyrite with variable

concentrations of $\mathrm{Fe}, \mathrm{Pb}, \mathrm{Cu}$

$\mathrm{Zn}, \mathrm{Pb}, \mathrm{Mo}, \mathrm{Sb}$, As sulfides ${ }^{5}$

Vein textures

Banded margins, massive

interiors, composed of anhedral

quartz with overprinting by

ribbons, styolites, spider

veinlets and breccias ${ }^{10}$

Alteration

Quartz $^{5}$

Carbonate (Ca-Fe-Mg)

Sericite / muscovite ${ }^{5}$

Chlorite $^{5}$

Albite $^{5}$

Fluids

$150-450^{\circ} \mathrm{C}$ (typically 275

$350^{\circ} \mathrm{C}$ ), $\mathrm{C}-\mathrm{O}-\mathrm{H} \pm \mathrm{N}$, near-neutral

to low $\mathrm{pH}$, typically $\leq 6 \mathrm{wt} \%$

$\mathrm{NaCl}$ equiv, (5- 50 mole

percent $\left.\mathrm{CO}_{2}\right)^{5}$

${ }^{1}$ Groves (2003)

${ }^{2}$ Simmons et al. (2005)

${ }^{3}$ Hitzman and Beaty (1996)

${ }^{4}$ The structures at Bohaun indicate an extensional tectonic regime and a major basin lies to the west

${ }^{5}$ Bierlein and Crowe (2000)

${ }^{6}$ Everett et al. (1999a)

${ }^{7}$ Absence of alkali feldspar and rare carbonate

${ }^{8} \mathrm{Absence}$ of adularia and rhodochrosite

${ }^{9}$ Fresh sulfides are extremely rare in the Bohaun mineralization. However, abundant iron oxide staining in auriferous samples in conjunction with minor sulfides observed in polished section suggest an association with the gold mineralization

${ }^{10}$ Dowling and Morrison (1990)

${ }^{11}$ Association of chlorite and sericite with gold, but not pervasive 